\title{
Chasing the Phantom Ship: Revisiting Interpretations of the Boca Chica No. 2 Shipwreck on the Texas Coast
}

Amy A. Borgens

Texas Historical Commission

Steven D. Hoyt

Texas Historical Commission

Follow this and additional works at: https://scholarworks.sfasu.edu/ita

Part of the American Material Culture Commons, Archaeological Anthropology Commons, Environmental Studies Commons, Other American Studies Commons, Other Arts and Humanities Commons, Other History of Art, Architecture, and Archaeology Commons, and the United States History Commons

Tell us how this article helped you.

This Article is brought to you for free and open access by the Center for Regional Heritage Research at SFA ScholarWorks. It has been accepted for inclusion in Index of Texas Archaeology: Open Access Gray Literature from the Lone Star State by an authorized editor of SFA ScholarWorks. For more information, please contact cdsscholarworks@sfasu.edu. 


\section{Chasing the Phantom Ship: Revisiting Interpretations of the Boca Chica No. 2 Shipwreck on the Texas Coast}

\section{Licensing Statement}

Reproduction, posting, transmission, or other distribution or use of the Journal volume, individual article or any portion of the material therein, in any medium, is permitted strictly for personal, non-commercial purposes via a personal-use exemption under a Creative Commons license granted by JTAH.org, Inc. This license exemption requires, as a condition of its granted permission, proper credit be attributed to JTAH.org as copyright holder (e.g., Journal of Texas Archeology and History.org @ 2019). No part of this publication may be reproduced, posted, transmitted, or otherwise utilized or distributed in any form by any means or method for commercial purposes without the express written consent of the Publisher. Inquiries should be addressed to JTAH Publisher, Suite 307, Box 361, 5114 Balcones Woods Drive, Austin, Texas, 78759.

The Journal of Texas Archeology and History.org is an organization dedicated to furthering research, education and public outreach in the fields of archeology and history concerning Texas and its bordering states of Louisiana, Arkansas, Oklahoma, New Mexico and Northern Mexico; a region we call the "Texas Borderlands." The J.T.A.H. is collaborating with the Index of Texas Archaeology and S.F.A.S.U. to distribute their publication library to the general public via free and open-access channels. Visit www.JTAH.org to submit an article. 


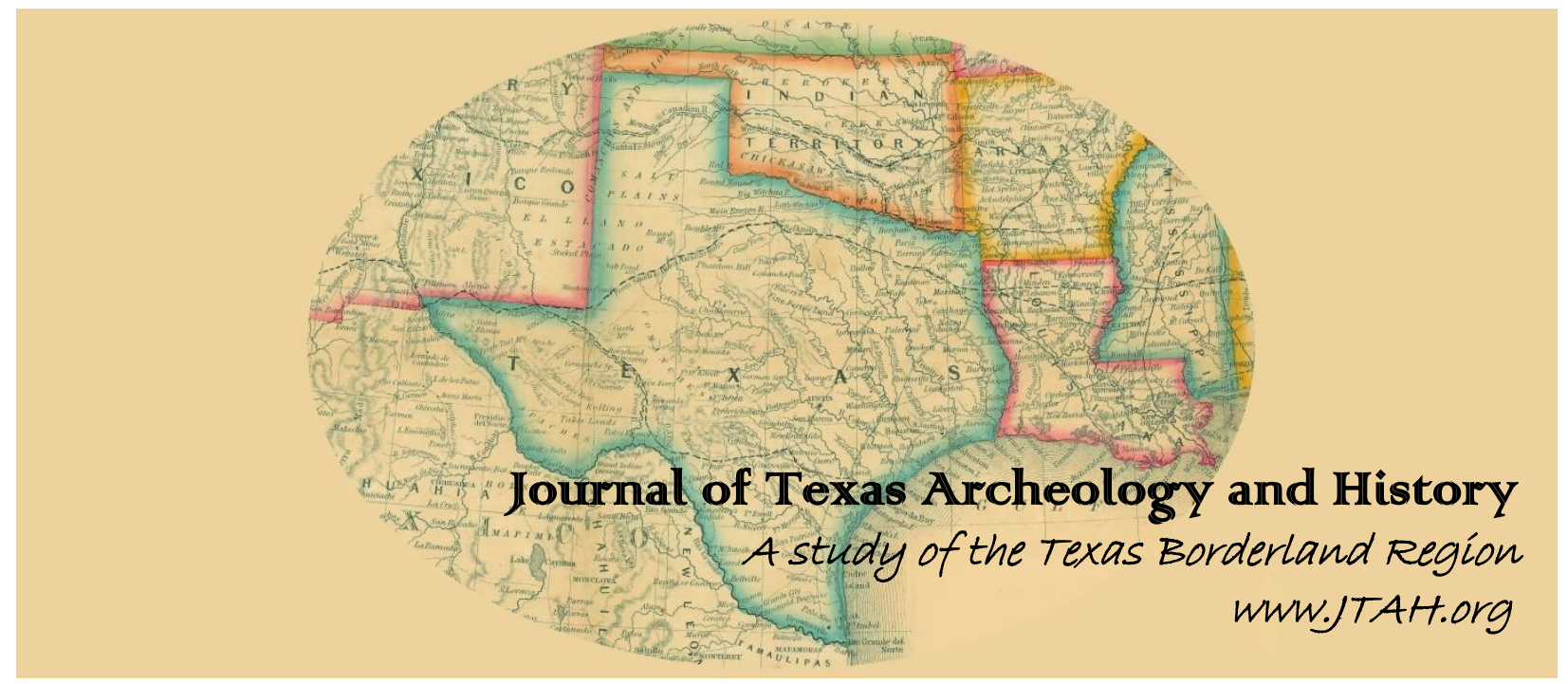

\section{Article Title: (reprint) CHASING THE PHANTOM SHIP: REVISITING INTERPRETATIONS OF THE BOCA CHICA NO. 2 SHIPWRECK ON THE TEXAS COAST}

Author(s): $\quad$ Amy A. Borgens, Texas Historical Commission with contributions by Steven D. Hoyt

Original Source: J.T.A.H. Volume 5 (2018/2019), Article 2, pp. 41 - 88; online 27 December 2019

Recommended Citation: Borgens, Amy A., and Steven D. Hoyt; a reprint of "Chasing the Phantom Ship: Revisiting Interpretations of the Boca Chica No. 2 Shipwreck on the Texas Coast", (2019), Journal of Texas Archeology and History Volume 5 (2018/2019), pp. 41 - 88.

Copyright $(2019$ by Journal of Texas Archeology and History.org, Inc. All rights reserved. Online/Digital publication: ISSN 2334-1874

The online, digital, and print versions of the publication "Journal of Texas Archeology and History" are published by Journal of Texas Archeology and History.org, Inc., a Texas nonprofit IRC Section 501(c)(3) corporation.

Reproduction, posting, transmission, or other distribution or use of the Journal volume, individual article or any portion of the material therein, in any medium, is permitted strictly for personal, non-commercial purposes via a personal-use exemption under a Creative Commons license granted by JTAH.org, Inc. This license exemption requires, as a condition of its granted permission, proper credit be attributed to JTAH.org as copyright holder (e.g.. Journal of Texas Archeology and History.org (C) 2019). No part of this publication may be reproduced, posted, transmitted, or otherwise utilized or distributed in any form by any means or method for commercial purposes without the express written consent of the Publisher. Inquiries should be addressed to JTAH Publisher, Suite 307, Box 361, 5114 Balcones Woods Drive, Austin, Texas, 78759.

The Journal of Texas Archeology and History.org is an organization dedicated to furthering research, education and public outreach in the fields of archeology and history concerning Texas and its bordering states of Louisiana, Arkansas, Oklahoma, New Mexico and Northern Mexico; a region we call the "Texas Borderlands." The J.T.A.H. is collaborating with the Index of Texas Archaeology and S.F.A.S.U. to distribute their publication library to the general public via free and open-access channels. Visit www.JTAH.org to submit an article. 


\title{
CHASING THE PHANTOM SHIP: REVISITING INTERPRETATIONS OF THE BOCA CHICA NO. 2 SHIPWRECK ON THE TEXAS COAST
}

\author{
Amy A. Borgens, Texas Historical Commission \\ with contributions by Steven D. Hoyt
}

\begin{abstract}
Boca Chica Beach spans the south Texas coast in Cameron County for a distance of roughly 12 kilometers between Brazos Santiago Pass and the mouth of the Rio Grande River at the Texas and Mexican border. More than 165 historic ships have been reported lost along the south Texas coast in this general area and at least four, or portions thereof, have been discovered so far. The most well-known of the shipwreck remains is archeological site 41CF184, nicknamed Boca Chica No. 2, which has gained almost mythological status in the region as it has long been circumstantially linked to the Mexican warship Moctezuma; not-so-coincidentally one of the most famous shipwrecks in the region. Is Boca Chica No. 2 the famous warship, once believed to be a "phantom" because it so often eluded the Texian patrols? Evidence suggests otherwise but the significance of both the historic ship and the archeological site invite reexamination of this unresolved mystery.
\end{abstract}

\section{INTRODUCTION}

Like other coastal shipwrecks discovered on the beach, site 41CF184, known as Boca Chica No. 2, for years has intrigued archeologists and the public alike. The shipwreck has been known to the Texas Historical Commission (THC) for almost two decades, during which time its periodic exposure on the beach near the mouth of the Rio Grande River (Figure 1) has allowed for semiregular monitoring and recordation. Artifacts have not been observed and there is a strong likelihood this vessel was heavily salvaged at the time of its loss, including perhaps parts of the ship itself. Local folklore has long suggested this might be the Mexican Navy vessel Moctezuma (often also referred to as Montezuma, Bravo, and General Bravo), supposedly sunk by the Texas Navy schooner Invincible in April of 1836. This is considered an important milestone in Texas history as Mexico had successfully employed this vessel to both deter Texians from receiving revolutionary supplies and assist in preparations for the Mexican military advance. The local hypothesis that Boca Chica No. 2 is Moctezuma has not been supported by any archeological or historical evidence.

\footnotetext{
JOURNAL OF TEXAS ARCHEOLOGY AND HISTORY

VOLUME 5:41-88

THE ONLINE PUBLICATION JOURNAL OF TEXAS ARCHEOLOGY AND HISTORY (ISSN 2334-1874)

IS PUBLISHED BY JOURNAL OF TEXAS ARCHEOLOGY AND HISTORY.ORG.

COPYRIGHT (C) 2019 JOURNAL OF TEXAS ARCHEOLOGY AND HISTORY.ORG. ALL RIGHTS RESERVED.
} 
A renewed look into the case of Moctezuma has only further emphasized the inherent difficulty in conclusively identifying historic shipwrecks with limited evidence and, more specifically, the problems with linking this vessel to site $41 \mathrm{CF} 184$. Historical research demonstrates at least three

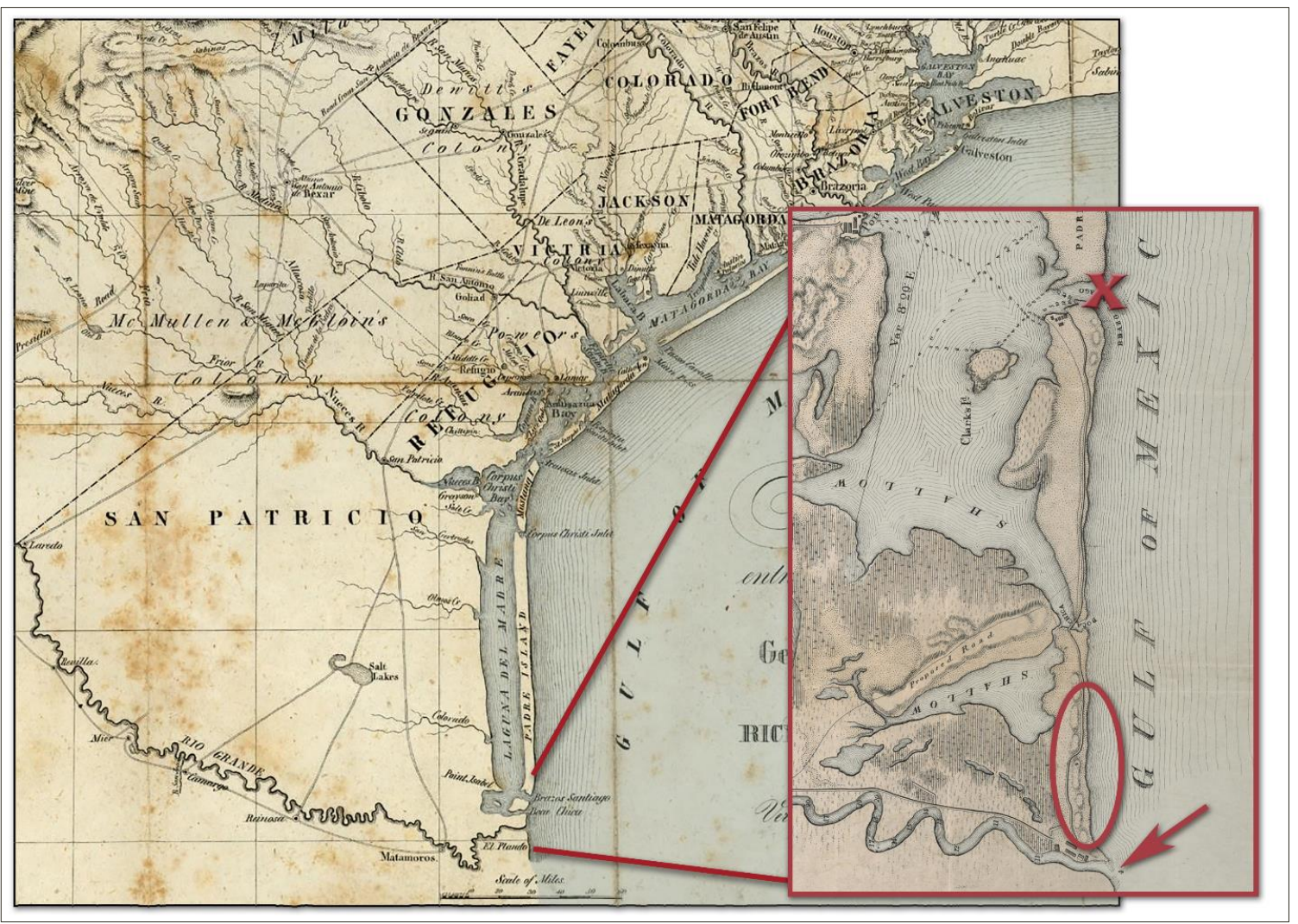

Figure 1. Color-modified maps from 1839 (Hunt and Randel 1841) with 1847 inset detail (Webster et al. 1847) showing Brazos Santiago Pass (X), the mouth of the Rio Grande River (arrow) and approximate location of 41CF184 (circle) (image by author, 2017).

armed sailing vessels called Montezuma/Moctezuma/Bravo/General Bravo were used by Mexico between 1825 and 1838 before a fourth steamship of that name (Montezuma) was acquired in 1842 . The 1830s naval vessel is reported to have been lost at both the Brazos Santiago Pass and the mouth of the Rio Grande River. Secondly, Mexican sources may suggest that Moctezuma survived the 1836 naval engagement and was still in use the following years. Can new research tease out the answer to this mystery?

\section{THE DISCOVERY}

Randy Blankenship of Texas Parks and Wildlife Department (TPWD) reported the archeological site to former State Marine Archeologist Steve Hoyt of the THC in 1999. It had become exposed following a storm and damaged by a Cameron County beach cleaning crew (Hoyt 1999a:1). Hoyt contacted the County Engineer's Office and requested a halt to work activities and 
visited the site in May 1999 (Figure 2). Portions of the bow and stern were exposed, and Hoyt observed 29 frames on the port side, some doubled. The observed frames were not evenly spaced with gaps of as large as $3.3 \mathrm{~m}(10 \% \mathrm{ft})$ as many were missing. Hoyt suggested that the framing gaps could be due to natural erosion beneath the sand line but speculated that this was likely caused by heavy equipment damage (Hoyt 1999a:3). A detached hanging knee and ceiling plank were previously recovered by TPWD and reviewed by Hoyt. The knee was recorded as having a broken, incomplete vertical height of $33.0 \mathrm{~cm}$ (13 in) and a horizontal length of $68.6 \mathrm{~cm}$ (27 in). The ceiling plank had an incomplete length of $2.9 \mathrm{~m}$ (9.5 ft) with a thickness of $3.8 \mathrm{~cm}$ (1.5 in) (Hoyt 1999a:4; Hoyt 1999b:6).

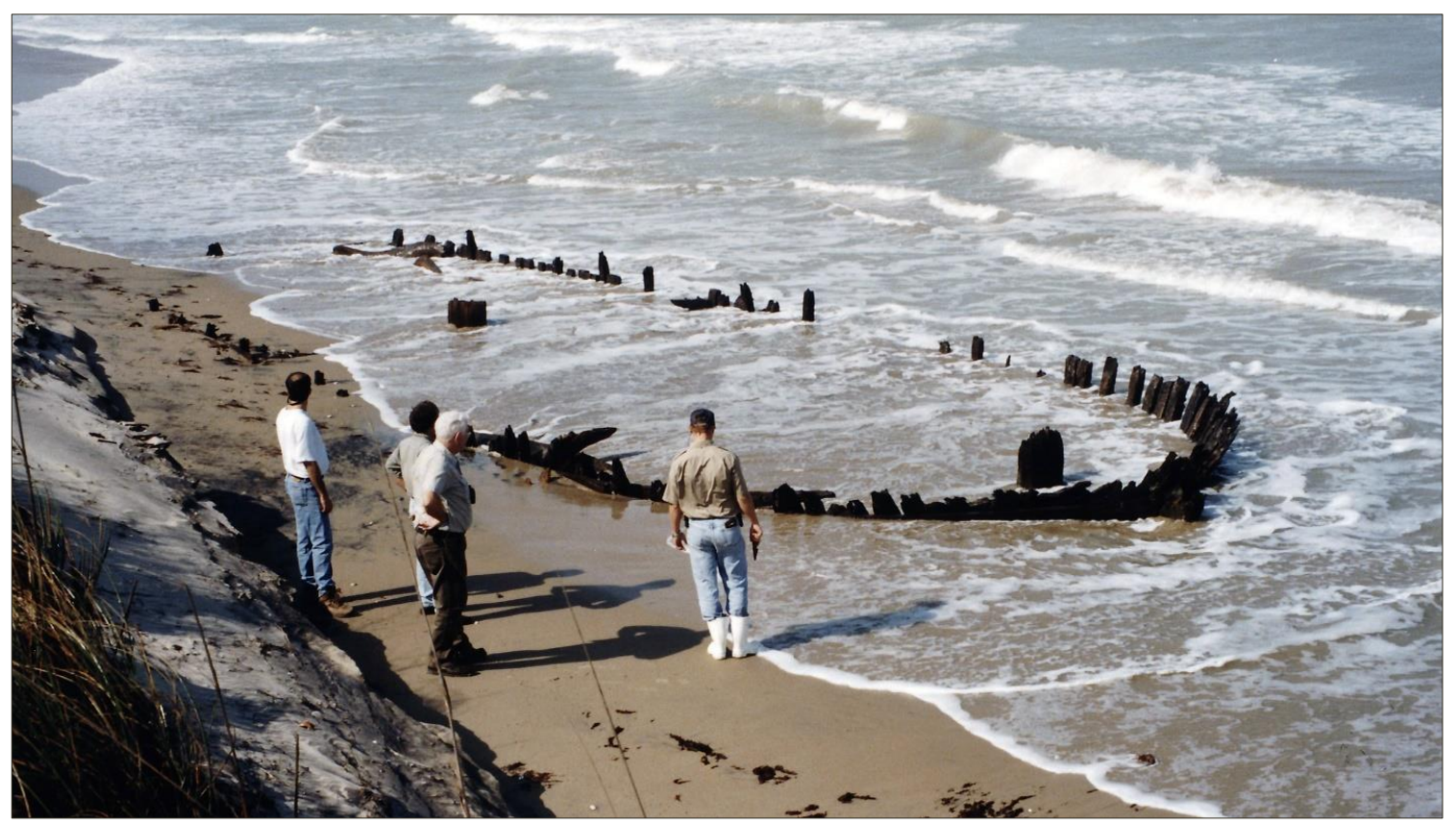

Figure 2. Site 41CF184 in 1999 (photo by Steve Hoyt, 1999).

Historic and prehistoric archeological sites such as this on state public lands are protected by Texas state law. Incidentally it was the unsanctioned recovery of artifacts from a 16th-century shipwreck off Padre Island that led to the enactment of the Antiquities Code of Texas in 1969 (Arnold and Weddle 1978:xiii-xiv). Texas thereby became one of the first states to create legislation that specifically protects historic shipwrecks. Boca Chica No. 2 was designated a State Antiquities Landmark in 2004, the highest protective status for a historic site that is issued by the state.

The THC, with help from its volunteer group (the marine stewards) and local citizens, have monitored the wreck since 1999 and have documented its migration from the dunes into the 
intertidal area. This has greatly accelerated the degradation of the hull timbers. The combined destructive forces of the wave action, wood consumption by the "shipworm" Teredo navalis, and injuries to the wreck through beach cleaning activities, vandalism, and looting have all contributed to the rapid decline of this important site.

Field observations and additional examination of the 1999 photography show that when site 41CF184 was first discovered, it still retained outer hull planks and internal ceiling planking, had two of its hanging knees (these support the deck beams; Figure 3), the sternpost, and gunwale stanchions projecting above the natural termination of the frames - all of which indicate that hull structure was once preserved at or above the deck level. Most of the hanging knees were missing, in addition to all of the deck beams, deck planking, and all superstructure and attributes typically situated atop the deck. The absence of these timbers could be due to environmental processes, but often beached wrecks could be salvaged not just for their cargo but also their robust timbersespecially in areas that were sparsely inhabited or lacked local abundant timber resources. Even in spite of its incomplete condition, site 41CF184 at its time of discovery constitutes one of the most complete and well-preserved shipwrecks ever discovered in Texas.

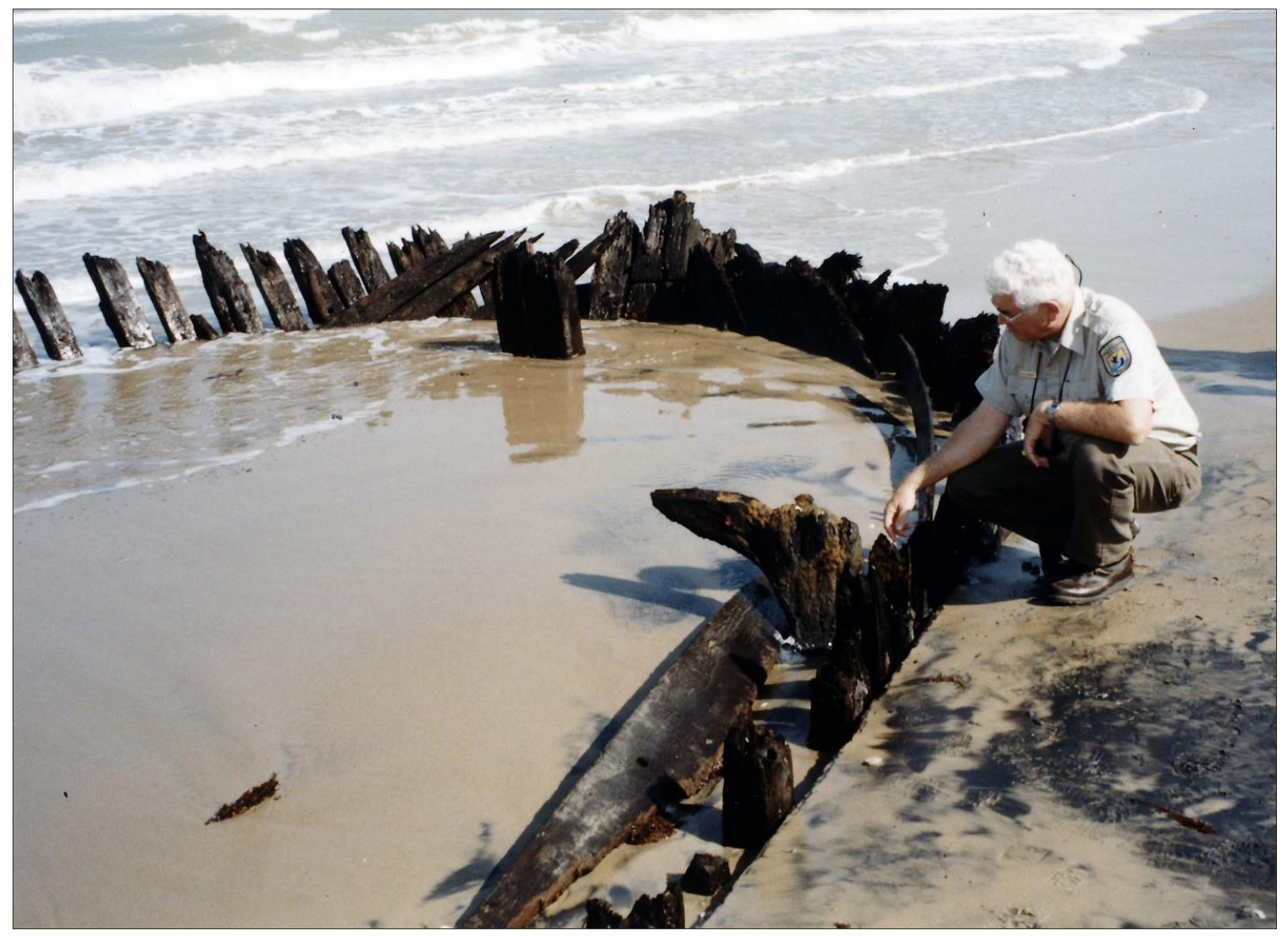

Figure 3. Detail of site 41CF184 showing exposed ceiling planking at the bow, hawse timbers, framing, starboard outer hull planking, a hanging knee, and the bowsprit step. (Photo by Steve Hoyt, 1999). 


\section{THE SHIP}

More extensive examination of 41CF184 occurred in 2002, at which point the vessel had again been uncovered. Steve Hoyt visited the shipwreck in May, almost three years to the day after his original introduction to the site. At this time Hoyt more extensively recorded many basic diagnostic attributes. He suggested the length overall (LOA) was $22.0 \mathrm{~m}(72.2 \mathrm{ft})$ with a maximum beam of $7.7 \mathrm{~m}$ (25.3 ft). He mapped the transom in detail and determined the width across the expanse of ceiling/deck planking measured $4.7 \mathrm{~m}$ (15.5 ft). The octagonal main mast measured $43.2 \times 44.5$ $\mathrm{cm}$ (17 in $\mathrm{x} 17.5 \mathrm{in}$ ) flat-to-flat. The chainplate on the port side was visible at this time. Hoyt recognized that ceiling planking observed at the bow in 1999 was missing (Hoyt 2002a:1-2). Previously in 1999, Hoyt recorded molded and sided dimensions of the futtocks as $15.2 \times 15.2 \mathrm{~cm}$ (6 x 6 in) (Hoyt 1999a:3).

Later in August 2002, the THC's marine stewards mapped the exposed timbers using trilateration (Figure 4). This work was largely undertaken by Andrew Hall, Gary McKee, Tom Oertling, John Luce, and Doug Nowell (Hall et al. 2002; Hoyt 2002b; Oertling 2002). This investigation determined $41 \mathrm{CF} 184$ was $21.9 \mathrm{~m}$ (72 ft) in preserved hull length with a hypothesized complete LBP (length between perpendiculars) of $24.1 \mathrm{~m}$ (79 ft) (Oertling 2002:3). A reexamination of the 1999 photography indicates that the hull was at or above the deck level, which is the point that LBP - the length from the fore part of the stem to the after part of the stern-was calculated for enrollment and registration for floating vessels (Lyman 1945:226); it is suggested in this article that the enrollment/registration length of 41CF184 likely did not exceed $22.9 \mathrm{~m}$ (75 ft) and was probably fairly close to the measured LBP of the hull.
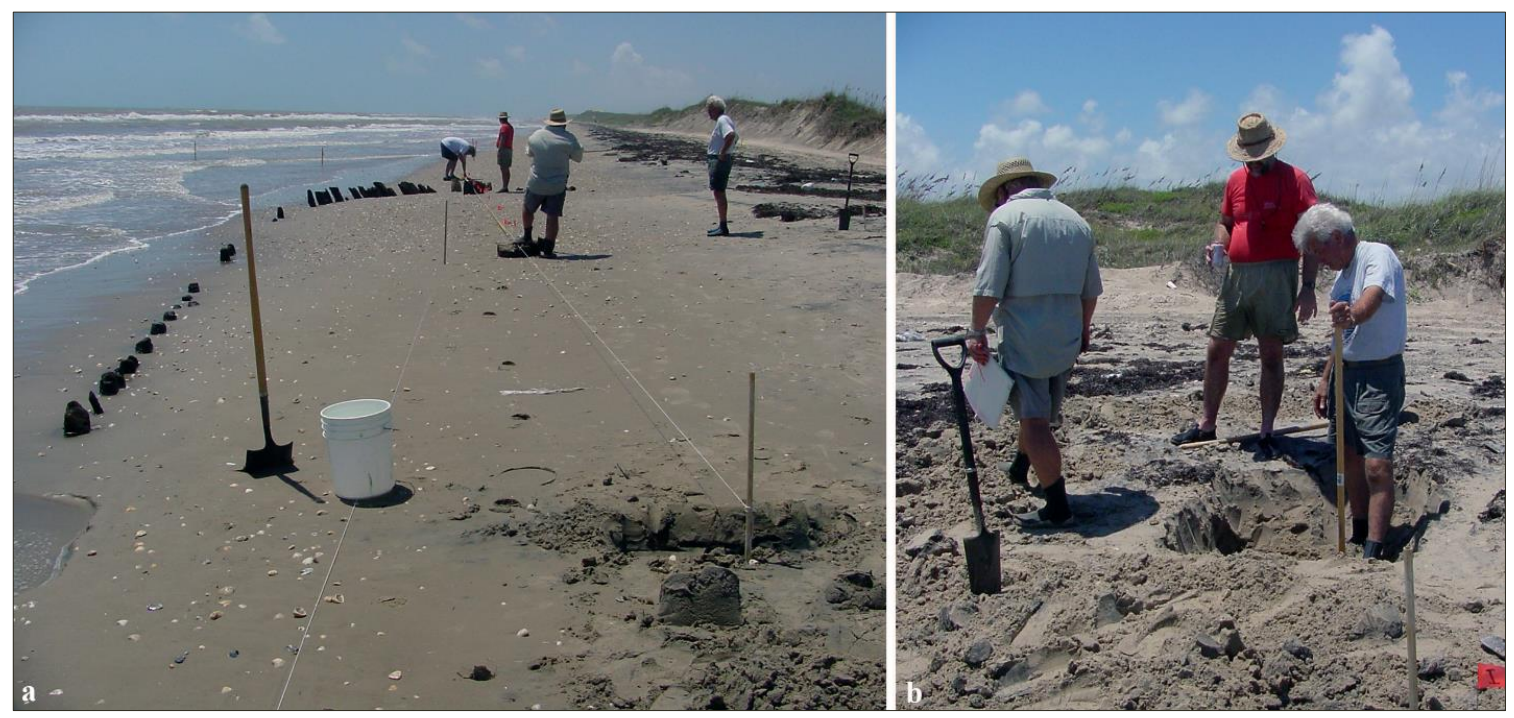

Figure 4. THC marine stewards mapping site 41CF184: (a) creating mapping datum points; (b) uncovering the stern (photos by Bill Pierson, 2002). 


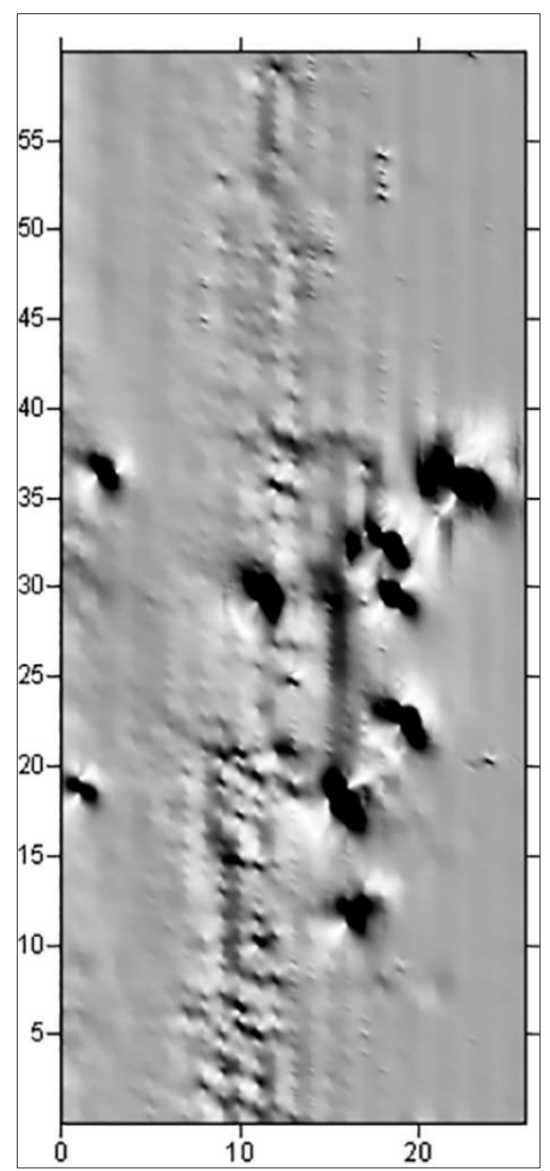

Figure 5. Magnetometer Map (Bill Pierson, 2002).
The maximum breadth, calculated using the measured half width of $3.5 \mathrm{~m}$ (11.5 ft) was $7.0 \mathrm{~m}$ (23 ft) (Oertling 2002:3). The vessel was both treenail and iron fastened (Oertling 2002:2). In 2002 the mainmast and bowsprit step (also bitt or knighthead) were the only internal central features exposed and an unsuccessful attempt was made to excavate and locate the foremast. Oertling focused on two attributes to help indicate an age for the shipwreck: the rake of the mainmast 5 degree aft and the semi-circular arrangement and pronounced rake of the hawse (bow) frames. Collectively these suggested to Oertling (2002:3) a 1790-1840 build date. A wood sample taken of a futtock (number P30) indicated it was oak (Oertling 2002:3).

In addition to mapping the wreck, THC staff Bill Pierson conducted a magnetometer survey of the beach at the wreck site (Figure 5). Only a portion could be surveyed due to the surf and this showed the locations of the iron fittings and fasteners within the largely wood fastened-hull (Hoyt 2002a:3).

Additional excavation and mapping of the shipwreck was planned for June 2006, through a joint collaboration between the Texas Historical Commission and the PAST Foundation. Unfortunately by the time the project was coming to fruition, the beach had dramatically eroded and Boca Chica No. 2 was in the intertidal area and surf zone. The PAST mapping project never commenced (Andrew Hall, personal communication 2017).

In 2016, the THC acquired the foremast that had been collected from the archeological site in 2010. The report of its removal had been shared by archeologist Mark Willis. He had been informed that it was removed so that it could be carved into a bird. The THC later learned that the prospective wood artisan recognized the foremast from the wreck so it was retrieved and stored in a local bait shop before it again changed hands. Upon learning the bait shop was closing, local resident Keith Reynolds asked if he could have the foremast. In an effort to find the true owner of the artifact, Reynolds contacted Bill Turner, then-president of the Texas Navy Association, who then contacted the THC (Borgens 2016a:2). In January 2016, Turner and the author visited 
Reynolds in Brownsville and collected the foremast. Currently this is the only portion of the shipwreck curated by the THC.

The remaining foremast represents the stump, essentially the bottom of the mast, where it would have been mortised into the keelson. It is believed to weigh more than $200 \mathrm{lbs}$. and even though it is heavily Teredo-damaged, the lower 38 to $50 \mathrm{~cm}$ (15.0-19.7 in) still retains its original surface. The mast was octagonal in shape, like the mainmast, with a distance between flats of 46.6 $\mathrm{cm}$ (18.3 in) at the base; the octagon planes are irregular and range in width from 12.8 to $21.2 \mathrm{~cm}$ (5.0 to $8.3 \mathrm{in}$ ). An iron band $9.2 \mathrm{~cm}$ high and $2.7 \mathrm{~cm}$ (3.6 and $1.1 \mathrm{in})$ thick was at the base of the mast. The overall preserved height of the foremast is $144.7 \mathrm{~cm}(4.8 \mathrm{ft})$ including the $129.8 \mathrm{~cm}(4.3$ in) mast and $14.9 \mathrm{~cm}$ (5.9 in) heel tenon (Borgens and Cabading 2016). The height of this artifact suggests that the preserved depth to the bottom of the keel was approximately $2.1 \mathrm{~m}(7 \mathrm{ft})$ or greater when the wreck was exposed in 2002, as this would have been attached to the keelson which overlies the frames and keel. By this time most of the frames were no longer preserved to their natural termination as evident in the 1999 photography. Wood sample analysis conducted by Macrobotanical Analysis for the THC in 2016 determined the foremast was fashioned from baldcyprus, a timber predominantly local to southern U.S. coastal states (Steffy 1994:257; Bush 2016). Masts could become easily damaged and were replaceable, therefore the origin of the wood only conclusively shows the origin of the mast itself, which may or may not represent where the ship was built.

An important consideration for deducing the age and potential function of a historic vessel is the presence of copper sheathing. So far over the years there has been no evidence of copper sheathing on site 41CF184 or the cupreous and copper fasteners associated with sheathed vessels. Copper sheathing emerged in the 1760 s as a military technology for sheathing and protecting submerged naval hulls from Teredo damage and fouling. Britain was the leader in developing this technology, being the first to copper sheath a ship, HMS Alarm, in 1761, and with more than 20 ships sheathed by 1777 (Staniforth 1985:23-24). France and the United States sheathed their first naval vessels Le Gorée and Alliance in 1767 and 1781, respectively (Boudriot 1986:241; Steffy 1994:175). Adoption of copper sheathing as hull protection was gradual due to the galvanic corrosion of the underlying iron fasteners. Once a successful "composition" cupreous fastener type was developed in the late 1780s, coppering became more widespread. By 1812 it was considered common practice in the construction of British vessels (Staniforth 1985:25; Pering 1812:36).

The use of copper sheathing for the United States Navy occurred later, with it only becoming a regular practice in the beginning of the nineteenth century. Though the U.S. had manufactured 


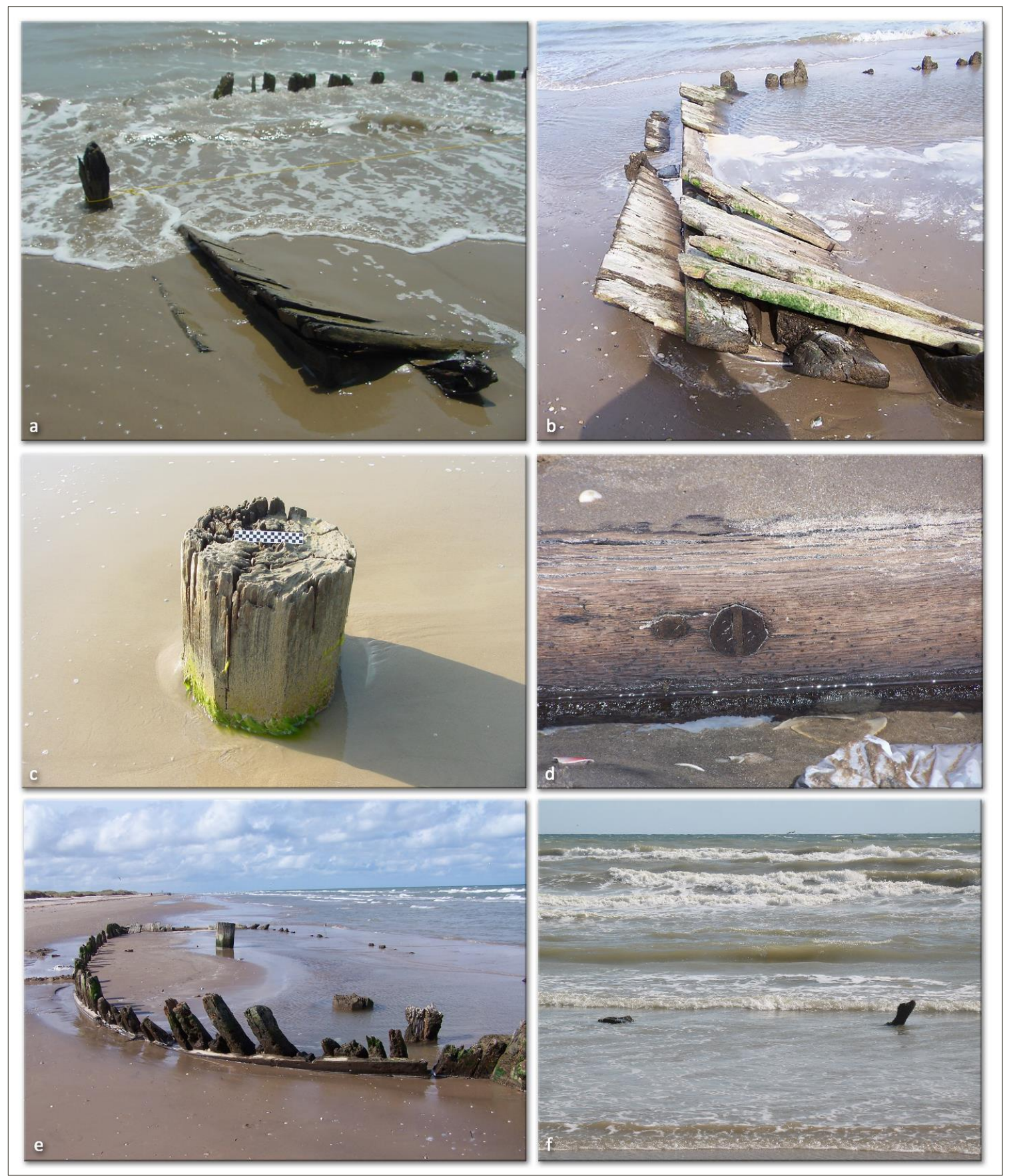

Figure 6. Details of 41CF184 since 1999: (a) transom in 2002 (photo by Steve Hoyt, 2002); (b) transom in 2005 showing more exposure, timber loss, and details of fashion pieces and outer planking (photo by Kay Polt, 2005); (c) the octagonal mainmast in 2002 (photo by Steve Hoyt, 2002); (d) Treenail with wedge (photo by Kay Polt, 2005); (e) Overall site from September 2005 showing both masts, bowsprit step, outer hull planking, and (far right) stem (photo by Kay Polt, 2005); (f) only the stem and foremast are visible in October 2009 demonstrating substantial loss and rapid degradation of remaining timbers (photo by Jeff Durst, 2009).

its own copper since 1815, it was unable to produce the requisite quantities and in 1850 it was still importing this commodity from Britain—enough to sheath 600 vessels (Kauffman 1968:117; Ronnberg 1980:125). By 1832 a new alloy copper sheathing (60 percent copper to 40 percent zinc) 
was patented by G. F. Muntz, though its use only began to supersede that of regular copper by the mid-nineteenth century (Staniforth 1985:23, 27). Copper sheathing technology gradually diffused to use on merchant and recreational vessels but during the early to mid-nineteenth century this still added a considerable expense to vessel construction and maintenance. Vessels advertised in the newspapers for charter promoted coppering such as the copper fastened and coppered Mexicano (New Orleans Bee [NOB] 1836a) as it alluded to a finer quality and better-maintained vessel.

As a general rule of thumb, the appearance of copper sheathing typically indicates a late eighteenth-century to late nineteenth-century use or manufacturing date for a shipwreck. On late eighteenth- and early-nineteenth century wrecks this can suggest naval use, as this was before it adopted for large-scale commercial use. Additionally, Muntz metal is typically used to theorize pre or post mid-nineteenth century dates. The lack of sheathing can also indicate pre-1780s dates as well but this needs to be coupled with other evidence as less costly constructed ships were frequently not coppered. The absence of sheathing on 41CF184 suggests a non-naval vessel of perhaps more humble origins.

\section{Photographic Monitoring}

Much of what has been learned about the shipwreck, aside from site mapping in 2002, is known from photographic monitoring (Figure 6). Prior to 2010, the THC files for 41CF184 contained images from 1999, 2002-2006, 2008, and 2009. In 2016 Kay Polt of the Power Squadron, donated additional photography she had taken in 2002, 2003, and 2005. Later in 2017, Harlingen resident Rebecca Lozano provided the earliest photos the THC now has on file, dating to the mid-1990s (Figure 7). The THC visited the location of 41CF184 in 2010 and 2016 and the shipwreck was not visible, therefore it could not be photo-documented (Borgens 2016a:4).

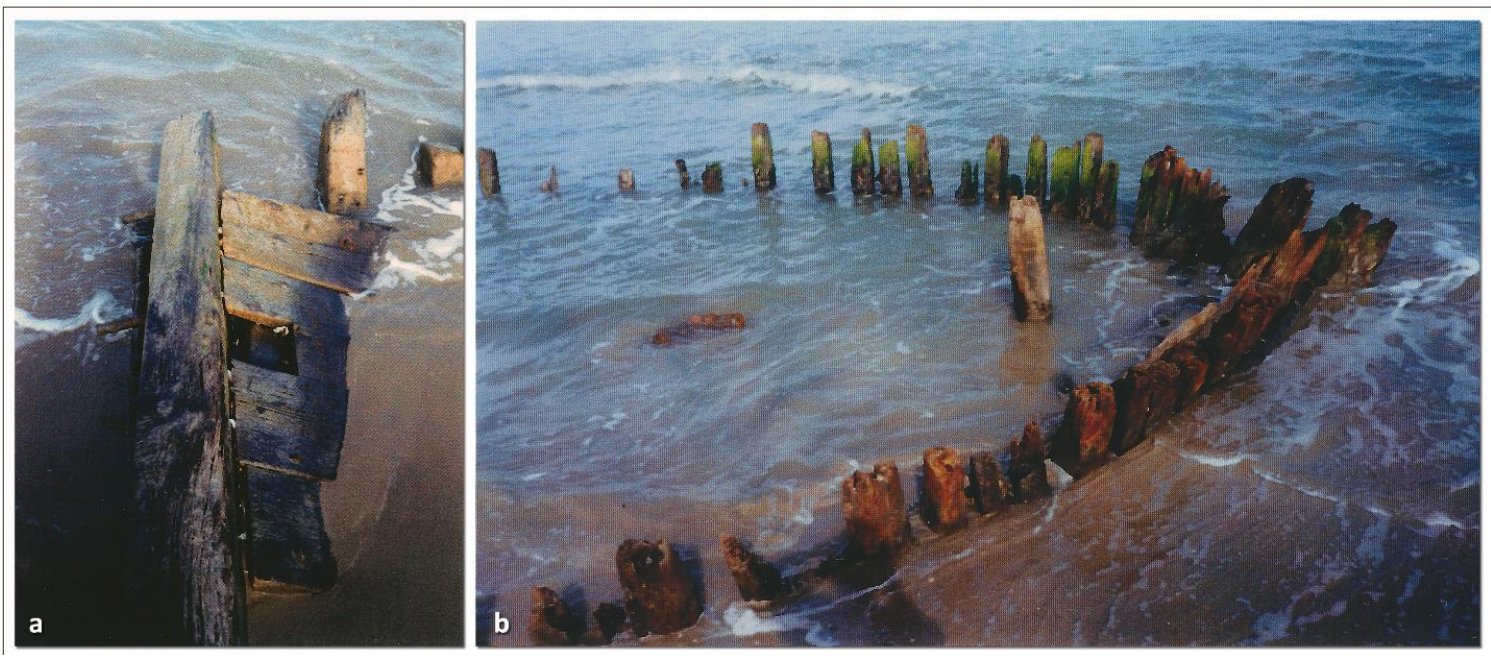

Figure 7. Early details of 41CF184: (a) port transom and (b) bow with foremast and bowsprit step visible (photos by Rebecca Lozano, ca. 1995). 
The Polt images were used to illustrate an online-article for the Texas Navy Association that proposed Montezuma as the identification of 41CF184 (Drake 2005) - this article is no longer hosted online. The THC photos from 1999 and May 2002 along with the Polt images from September 2005 provide some of the best imagery of the shipwreck when the majority of the upper buried attributes were visible. A series of photographs taken by Hoyt in 2002 captured the run of all the port and starboard frames from the vantage point of the centerline. Lozano's photos from ca. 1995 are the first on file that show the exposed foremast - this feature was often buried under sediment. Polt's 2005 images show important framing details and provide the best documentation of one of the treenails. This demonstrates that the treenail ends were finished with a wedge bisecting the circumference of the tip.

In 2016, the author augmented the 2002 Andrew Hall site map by adding the transom recorded by Hoyt in 2002 and then interpolating the position of the remaining frame ends, the outer hull planks, bow ceiling planking, and the foremast from photography (Figure 8). The spacing between the sets of double frames, as deduced from photography, was approximately $15.2 \mathrm{~cm}$ (6.0 in) (Borgens 2016b:18).

\section{Comparative New Orleans Vessel Statistics}

In 2006, the author created a database version of volume 1 (1804-1820) of the New Orleans Registers and Enrollments (Survey of Federal Archives in Louisiana 1941) which can be used to statistically analyze comparative vessel sizes for watercraft that may have frequented this important historic Gulf port during the early 19th century. This data has been used in other studies, notably the Mardi Gras Shipwreck project wherein averages were generated for vessel sizes (Ford et al. 2008, Ford et al. 2010; Horrell and Borgens 2017). Based on this data, the average length and maximum beam for all schooners in volume 1 was $18.2 \times 5.4 \mathrm{~m}(59.6 \times 17.7 \mathrm{ft})$ and $23.3 \times 6.9 \mathrm{~m}$ (76.3 x $22.8 \mathrm{ft}$ ) for brigs (Borgens 2008:58, Table 4.2). The size of the hull of 41CF184 therefore closely corresponds to the average merchant brig registered and enrolled at New Orleans between 1804 and 1820. 


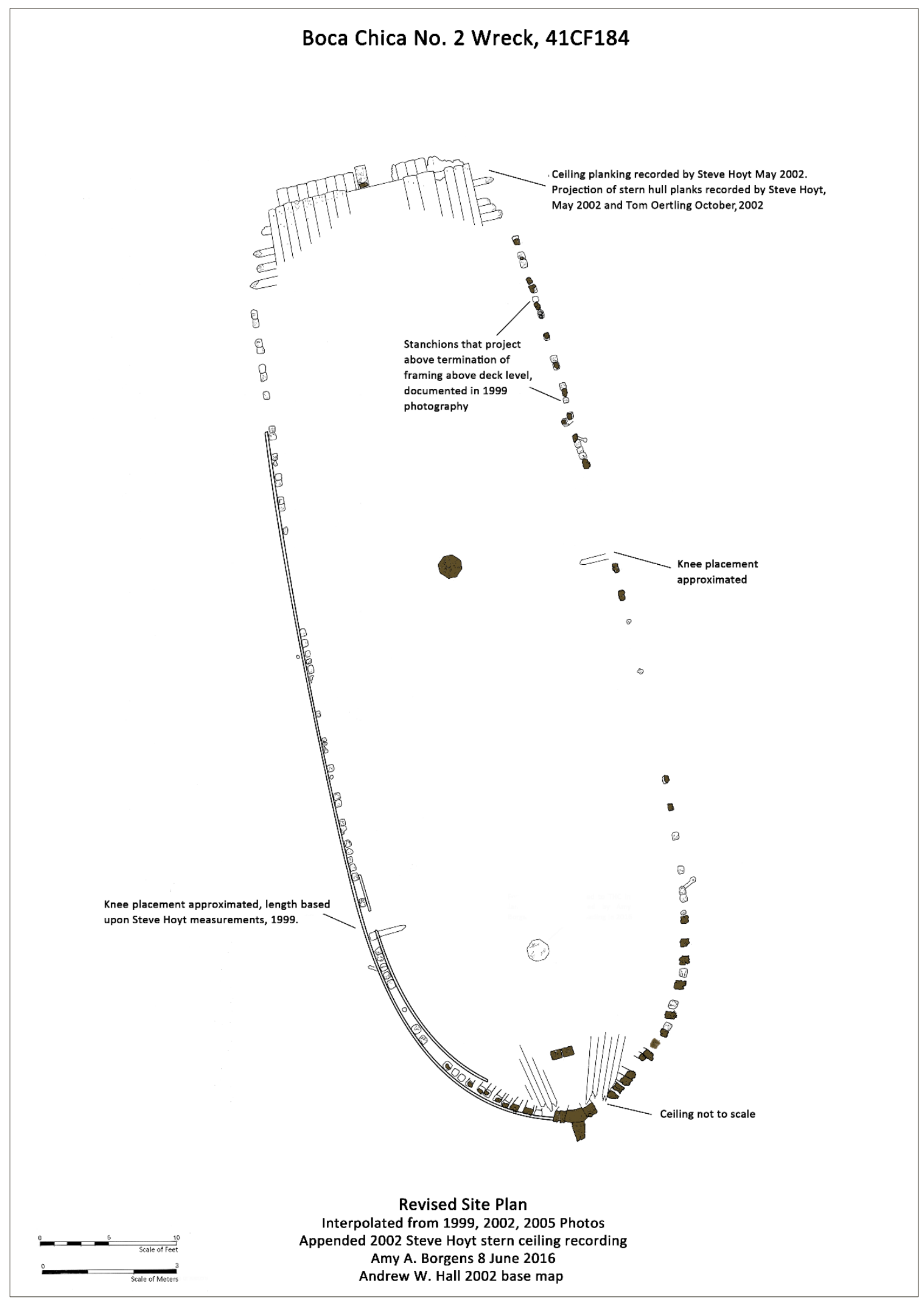

Figure 8. Revised site plan. Timbers depicted in the 2002 map are highlighted (Borgens and Hall, 2016). 
Almost half the 924 entries in volume 1 were two-masted vessels; such data was missing for $9 \%$ of the watercraft. Using the preserved hull LBP of $(21.9 \mathrm{~m} 72 \mathrm{ft})$ and an approximated hypothetical preserved LBP of $22.9 \mathrm{~m}$ (75 ft), two-masted New Orleans entries ranging in length from 21.9-22.9 m (72-75 ft) from volume 1 were compared $(n=29)$ : 14 were schooners, 14 were brigs, and there was a single snow. All but two vessels in these categories were listed as having a single deck-these exceptions both being brigs. The two-masted sailing vessels in this size range all had a square stern. The average for sailing vessels in this range specifically is $22.3 \times 6.6 \mathrm{~m}(73.3$ $\mathrm{x} 21.7 \mathrm{ft}$ ). The tonnages for vessels of this length are quite variable, ranging from 44 to 169 tons displacement, with an average of 127.9. The depth of hold ranged from 1.2-3.0 m (4 to $10 \mathrm{ft}$ ) with an average of $2.8 \mathrm{~m}(9.1 \mathrm{ft})$. Based on the New Orleans data for 1804-1820 and more specifically for the $21.9-22.9 \mathrm{~m} \mathrm{(72-75} \mathrm{ft})$ size range, $41 \mathrm{CF} 184$ conforms equally to a single-decked, twomasted merchant brig or schooner. The type of rigging more than the hull shape was typically the distinguishing factor between a brig and a schooner.

The length-to-beam ratio for the preserved hull of $41 \mathrm{CF} 184$ is $3.1: 1$; the adjusted length-to-

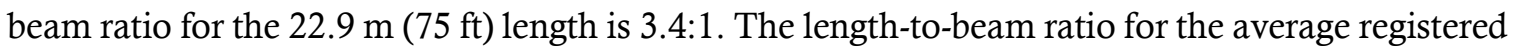
and enrolled merchant schooner is 3.4:1 and brig is 3.3:1. The average for two-masted sailing vessels in general for the $21.9-22.9 \mathrm{~m}(72-75 \mathrm{ft})$ range is 3.4. By comparison the length to beam ratio for the 83-ft. schooners of the Texas Navy (San Antonio, San Bernard, and San Jacinto) launched in 1839 was 3.9:1; the 110-ft. brigs Archer and Wharton were also 3.9 (Dawson and Williams 1839). Essentially, armed warships are typically longer for their beam than are merchant vessels.

In summary, 41CF184 is hypothesized to be a two-masted, wooden-hulled, double framed, and largely wooden-fastened sailing schooner dating from the late-eighteenth to the mid-nineteenth centuries. It is heavily built and has an overall length to beam ratio of approximately $3.4: 1$, which is more consistent with the "fatter" cargo carrying merchant vessels and not necessarily typical for the conventional finer, sharper-hulled warships of the time. The lack of sheathing on 41CF184 for this period is again suggestive of mercantile use and not naval purposes.

\section{EXAMINING MONTEZUMA AS A WRECK CANDIDATE}

The belief that 41CF184 is Montezuma has long persisted despite evidence to the contrary. This is unfortunately often the case for historic shipwrecks wherein local folklore can sometimes immediately associate an archeological site with the most famous shipwreck in the area. Generally, Texas wrecks are often attributed by local mythology to be either Spanish galleons, Civil War wrecks, or pirate ships belonging to Jean Lafitte. The question therein is, what is currently known about Montezuma to suggest it as a candidate for Boca Chica Shipwreck No. 2? 
This begins as a tale of four (maybe five) Moctezumas/Montezumas/Bravos, all of which appear to have been conflated with one another over the years. Both the author and Steve Hoyt independently developed timelines summarizing the history of Montezuma in the Gulf and chronicling the change in the vessels' names. These timelines have been combined and are included as Table 1. 


\section{Table 1. Timeline Summary of the Various Vessels by the Names of Ariel, Bravo, General Bravo, Montezuma, and Moctezuma}

\begin{tabular}{|c|c|c|}
\hline Date & Event & Names \\
\hline 1824 & $\begin{array}{l}\text { Bravo was purchased from England in } 1824 \text { and was formerly built as a nobleman's yacht named } \\
\text { Ariel (Bidwell 1960:331). Bonilla (1946:23) has } 1823 \text { as the purchase date. }\end{array}$ & Ariel \\
\hline 1824 July & $\begin{array}{l}\text { More than } 20 \text { royal yachts of the Royal Yacht Club, including Ariel, joined Commodore Lord } \\
\text { Yarborough's squadron ahead of the meeting at Plymouth (London St. James and General } \\
\text { Evening Post 1824:4) }\end{array}$ & \\
\hline $\begin{array}{l}1824 \\
\text { Aug. } 26\end{array}$ & Harborough's yacht sighted heading west of Deal (Courier 1825:3). & \\
\hline 1824 & $\begin{array}{l}\text { Bidwell surmises Ariel was purchased from England around August of 1824; however, he also } \\
\text { recognizes that Victoria and Bravo do not fit the description "two [frigates] of 44" by José Mariano } \\
\text { de Michelena in an August 31, } 1824 \text { letter (Bidwell 1960:331). Bonilla mistakenly (1946:23) has } \\
1823 \text { as the purchase date. }\end{array}$ & Ariel \\
\hline $\begin{array}{l}1825 \\
\text { Aug. } 6\end{array}$ & $\begin{array}{l}\text { An index of documents in the English archives relating to Mexico mentions a French letter of } \\
\text { August 6, } 1825 \text { that provides information on the ships Avend-Prindien and Ariel (Grajales } \\
\text { 1969:84). These were two of the three ships purchased through new loans negotiated with } \\
\text { English lending houses. Avend-Prindien was renamed Libertad and had been expected to arrive } \\
\text { in January but did not arrive in Mexico until September } 13 \text { (Bidwell 1960:349). All three vessels } \\
\text { arrived in the fall of } 1825 \text { as Victoria reached Mexico on August 18, 1825 after stops in New York } \\
\text { and Jamaica and Bravo arrived on September 20th (Bidwell 1960:349). }\end{array}$ & Ariel \\
\hline 1825 & Lord Harborough's yacht was mistakenly searched for spirits and contraband by an officer of the & \\
\hline Aug. & $\begin{array}{l}\text { "Preventative Service." When Lord Harborough questioned the reason for the search he was } \\
\text { challenged to a duel by Lieutenant Graham. Graham was convicted of provoking the duel and the } \\
\text { event was used an example of abuse of power by the military. The yacht [presumed to be Arie]] } \\
\text { was described as looking like a fishing vessel as a justification for why it was searched as it did } \\
\text { not look like a vessel of a nobleman (Kent and Essex Mercury 1825:4). }\end{array}$ & \\
\hline 1825 & $\begin{array}{l}\text { Ariel is outfitted as a warship at Gravesend, England in the fall of 1825, over a period of three } \\
\text { weeks (York Herald 1825, von Mach, personal communication 2018). }\end{array}$ & Ariel \\
\hline 1825 July & $\begin{array}{l}\text { Ariel, master Dillon, disembarks from Gravesend, England on July } 9 \text { for New York, stopping at } \\
\text { Deal on July } 12 \text { (London Lloyd's List [LLL] 1825a:1; 1825b). On July } 29 \text {, Arie/ would continue on } \\
\text { its voyage to New York, now departing from Falmouth with the vessel "Arve Prinsen" (LLL } \\
\text { 1825c). }\end{array}$ & Ariel \\
\hline 1825 & $\begin{array}{l}\text { Bravo and Libertad, formerly Ariel and Aven Prinsen, depart Falmouth, England (Michelena 1825; } \\
\text { von Mach, personal communication 2018). }\end{array}$ & Ariel, Bravo \\
\hline $\begin{array}{l}1825 \\
\text { Sept. } 20\end{array}$ & $\begin{array}{l}\text { Victoria arrives in Mexico on August 18, } 1825 \text { after stops in New York and Jamaica and Bravo } \\
\text { arrived on September 20th (Bidwell 1960:349). }\end{array}$ & Bravo \\
\hline $\begin{array}{l}1825 \\
\text { Sept. }\end{array}$ & $\begin{array}{l}\text { The ministerio de hacienda (treasury minister) Ignacio Esteva, inspected the navy and } \\
\text { commented on the weakened condition of Bravo (Escamilla 2008:245). }\end{array}$ & Bravo \\
\hline $\begin{array}{l}1825 \text { Oct. } \\
5\end{array}$ & $\begin{array}{l}\text { One of several vessels ordered to attack Spanish ships sighted off Veracruz including Libertad, } \\
\text { brigs Victoria and Bravo, schooners Paploapan, Tampico, and Orizaba, and the sloop Chalco } \\
\text { (Bonilla 1946:94). }\end{array}$ & Bravo \\
\hline
\end{tabular}




\section{Table 1. Timeline Summary of the Various Vessels by the Names of Ariel, Bravo, General Bravo, Montezuma, and Moctezuma}

\begin{tabular}{|c|c|c|}
\hline Date & Event & Names \\
\hline 1825 & Bravo's launch approached the Spanish fortress at San Juan de Ulúa to see how close they & Bravo \\
\hline Nov. & could get without detection (Bidwell 1946:370). & \\
\hline 1826 & $\begin{array}{l}\text { Another document in the English archives relating to Mexico provides general information on the } \\
\text { frigates Libertad, Ariel, and Victoria (Grajales 1969:103). At this juncture Ariel is formally part of } \\
\text { the Mexican Navy yet not being referred to as Bravo in this letter. }\end{array}$ & Ariel \\
\hline 1826 May & $\begin{array}{l}\text { New Commodore Porter arrives in Veracruz and witnesses the existing Mexican Navy: small } \\
\text { frigate Libertad of } 32 \text { guns, mostly carronades; old brig Victoria with } 18 \text { 18-pounders; Guerrero; } \\
\text { Bravo brig of } 1424 \text {-pounder carronades; Herman, hermaphrodite brig of } 5 \text { guns; and two small } \\
\text { schooners stationed at Campeche (Porter 1875:348,352). }\end{array}$ & Bravo \\
\hline 1827 Jan. & Listed as a ship in the Mexican Navy (Ward 1828:307-308; Bonilla 1946:109). & Bravo \\
\hline 1826 & Bravo arrives off Key West in December as part of the Mexican fleet's enterprise to capture & Bravo \\
\hline Dec. & Spanish prizes off Veracruz (Viele 1999:107). & \\
\hline 1827 & Listed as part of the Mexican fleet off of Key West with 18 guns and a crew of 100 . Also mentions & Bravo \\
\hline March & $\begin{array}{l}\text { Libertad } 40 \text { guns, } 250 \text { men), Victoria (18 guns, } 80 \text { men) and a schooner. The crew of this fleet } \\
\text { was comprised of } 2 / 3 \text { "Indians" and 1/3 American and English (New Times 1827:2). }\end{array}$ & \\
\hline $\begin{array}{l}1827 \\
\text { April } 25\end{array}$ & $\begin{array}{l}\text { Bravo captures Jovena Maria off of Salt Key Bank, which is near the Bahamas between the } \\
\text { Florida Keys and Cuba (LLL 1827:1). }\end{array}$ & Bravo \\
\hline $\begin{array}{l}1828 \\
1828 \text { July } \\
31\end{array}$ & $\begin{array}{l}\text { Bravo was part of the navy operating off of Cuba and had captured } 13 \text { prizes (Bonilla 1946:102). } \\
\text { The weak force of the Mexican Navy described as it appeared at Veracruz on July 31, 1828: } \\
\text { Congress } 64 \text { guns, Libertad of } 36, \text { Bravo of } 18 \text { guns, and two schooners (London Morning Post } \\
\text { 1828:3). }\end{array}$ & $\begin{array}{l}\text { Bravo } \\
\text { Bravo }\end{array}$ \\
\hline $\begin{array}{l}1832 \\
\text { Sept. } 4\end{array}$ & $\begin{array}{l}\text { Reported from New Orleans that the Mexican Schooner Montezuma of Tampico, Captain } \\
\text { Villareal, was captured by Grampus, Captain Tatnall, with } 37 \text { soldiers and a crew of } 43 \text { (British } \\
\text { Traveler and Commercial Law and Gazette 1832:2; Washington National Intelligencer: 1832:3; } \\
\text { Niles' Weekly Register 1832:82-83). It was captured off the Tampico River for piracy committed } \\
\text { near Matanzas. Montezuma was unlawfully fitted out by Mexican generals as part of an uprising } \\
\text { against the Mexican government. It carried a pivot and two other guns (Jones 1878: 39). Villereal } \\
\text { was convicted of piracy in U.S. courts and the vessel was not turned over to Mexico as } \\
\text { requested. }\end{array}$ & Montezuma \\
\hline 1833 & $\begin{array}{l}\text { Schooner Montezuma, captain Don Tomas Marin traveled to Matamoras with troops and in } \\
\text { November traveled to New Orleans with troops (Bonilla 1946:118). }\end{array}$ & Montezuma \\
\hline $\begin{array}{l}1834 \\
\text { April } 17\end{array}$ & $\begin{array}{l}\text { Schooners of war Moctezuma and Consolation (79 tons) and the 111-ton pilot-boat schooner } \\
\text { Correo de Tampico arrive at Veracruz (Procurador del Pueblo 1834; von Mach, personal } \\
\text { communication 2018). }\end{array}$ & Montezuma \\
\hline 1835 * & $\begin{array}{l}\text { By 1835, the navy of } 1829 \text { (when Porter left) was reduced to brig Veracruzano and schooner } \\
\text { Moctezuma. According to Bonilla, this encouraged the purchases of 1836: Iturbide, Vencedor del } \\
\text { Alamo, Libertador, Mexicano, General Bravo, General Cos, and General Urrea (Lerdo de Tejada } \\
\text { 1857:5; Bonilla 1946:118). The budget for } 1835 \text { was } \$ 826,584 \text { (Bonilla 1946:118). }\end{array}$ & $\begin{array}{l}\text { Moctezuma, } \\
\text { General } \\
\text { Bravo }\end{array}$ \\
\hline
\end{tabular}


Table 1. Timeline Summary of the Various Vessels by the Names of Ariel, Bravo, General Bravo, Montezuma, and Moctezuma

\begin{tabular}{|c|c|c|}
\hline Date & Event & Names \\
\hline $\begin{array}{l}1835 \text { May } \\
3\end{array}$ & $\begin{array}{l}\text { Seizure of the American schooner Martha from New Orleans by John Calva, first Lieutenant in } \\
\text { charge of Mexican Schooner Montezuma (Washington Globe 1835:2; Forysth 1836). }\end{array}$ & Montezuma \\
\hline $\begin{array}{l}1835 \text { May } \\
7\end{array}$ & $\begin{array}{l}\text { Some passengers traveling on the warship Moctezuma in } 1835 \text { did not have passports (Tenorio } \\
\text { 1835a). }\end{array}$ & Moctezuma \\
\hline $\begin{array}{l}1835 \text { May } \\
18\end{array}$ & Arrival of warship Moctezuma with troops and money (Tenorio 1835b). & Moctezuma \\
\hline $\begin{array}{l}1835 \text { July } \\
5\end{array}$ & $\begin{array}{l}\text { Letter from Eduardo Gritten to Domingo de Ugartechea stating his belief that an American ship } \\
\text { was expressly seeking the national schooner of war Moctezuma (Gritten 1835:204). }\end{array}$ & Moctezuma \\
\hline $\begin{array}{l}1835 \\
\text { Sept. }\end{array}$ & $\begin{array}{l}\text { The 4-gun Montezuma has an engagement with Ingham. Montezuma has a 50-man crew } \\
\text { wherein Ingham has } 4 \text { guns and only } 24 \text {. Ingham ran towards shore and is stated to have } \\
\text { commenced the attack (London St. James Chronicle and General Evening Post 1835:4). }\end{array}$ & Montezuma \\
\hline $\begin{array}{l}1835 \text { Oct. } \\
2-9\end{array}$ & $\begin{array}{l}\text { Montezuma was at Veracruz fitting out to take on arms and munitions to General Cos, but was } \\
\text { not ready in time to sail with the packet-it is suspected these will be landed at Matagorda Bay. } \\
\text { There was a temporary embargo at Veracruz from Nov 2-9 [possibly to keep this information } \\
\text { secret....] (London Public Ledger 1835:3). }\end{array}$ & Montezuma \\
\hline $\begin{array}{l}1835 \text { Oct. } \\
28\end{array}$ & $\begin{array}{l}\text { Report that "Montazuma," now Bravo, has been ordered to cruise Aransas without troops (Bryan } \\
\text { 1835). }\end{array}$ & $\begin{array}{l}\text { Montazuma, } \\
\text { Bravo }\end{array}$ \\
\hline $\begin{array}{l}1835 \text { Oct. } \\
28\end{array}$ & $\begin{array}{l}\text { A Mexican cruiser is "off of this place" (letter is from Quintana) and has been seen over the } \\
\text { previous two days-it fired a shot at Velasco which fell short of shore. Brinkley (ed.) assumes this } \\
\text { is Montezuma (McKinney and Williams 1835a). }\end{array}$ & Montezuma \\
\hline $\begin{array}{l}1835 \\
\text { Nov. } 4\end{array}$ & $\begin{array}{l}\text { Moctezuma fired at Velasco and cannon fire was returned from the shore, at which point } \\
\text { Moctezuma retreated. On the } 28 \text { th volunteers on San Felipe went in pursuit first towards } \\
\text { Galveston, then heading towards Matagorda where they found it anchored. San Felipe waited for } \\
\text { a smoother sea to commence attack but was instead wrecked on shore. Moctezuma and San } \\
\text { Felipe, aground, exchanged fire (Fisher 1836; McKinney 1835a; Powers 2006:80). }\end{array}$ & $\begin{array}{l}\text { Montazuma, } \\
\text { Moctezuma, } \\
\text { Montezuma } \\
\text { Bravo }\end{array}$ \\
\hline $\begin{array}{l}1835 \\
\text { Nov. } 9\end{array}$ & $\begin{array}{l}\text { McKinney is in Matagorda fitting out another vessel to go after Montezuma (San Felipe is lost ca. } \\
\text { Nov 6). McKinney believes a vessel named Crawford caused the wreck of San Felipe as } \\
\text { Montezuma was in Brazos Santiago on the 28th. Veracruzana is also off Matagorda and they } \\
\text { want two more commissions (McKinney and Williams 1835b). }\end{array}$ & Montezuma \\
\hline $\begin{array}{l}1835 \\
\text { Nov. } 14\end{array}$ & $\begin{array}{l}\text { Mentions the schooner Montezuma and "Vera Cruzana" (off Galveston) are cruising in the Gulf. } \\
\text { Montezuma was in Brazos Santiago from information received six days ago. Also mentions, } \\
\text { perhaps mistakenly that San Felipe was gotten off (McKinney 1835b). }\end{array}$ & Montezuma \\
\hline $\begin{array}{l}1835 \text { Nov } \\
19\end{array}$ & $\begin{array}{l}\text { Bravo drives Hannah Elizabeth aground and puts on board a prize crew (Fannin 1835:158-159; } \\
\text { Dienst 1909a:184). Another account calls this vessel General Bravo (Tornel 1836). Five } \\
\text { Americans taken by force and imprisoned at Brazos Santiago (Smith 1835:173). Mexican } \\
\text { authorities argue they were warranted in their actions as Hannah Elizabeth was carrying } \\
\text { contraband canon and arms (Guerra 1835:188). William Robbins retakes Hannah Elizabeth and } \\
\text { captures its prize crew. The Mexican Lt. says he is of Bravo and not Montezuma. Twelve } \\
\text { Mexican crew were captured, one died of exposure and drunkenness (Fisher 1835). }\end{array}$ & $\begin{array}{l}\text { Bravo, } \\
\text { General } \\
\text { Bravo }\end{array}$ \\
\hline
\end{tabular}




\section{Table 1. Timeline Summary of the Various Vessels by the Names of Ariel, Bravo, General Bravo, Montezuma, and Moctezuma}

\begin{tabular}{|c|c|c|}
\hline Date & Event & Names \\
\hline $\begin{array}{l}1836 \text { Jan } \\
8\end{array}$ & $\begin{array}{l}\text { Another mention of the Mexican sloop of war Moctezuma as being in the bay of Galveston and } \\
\text { that Texas does not have a navy to contest its presence - Invincible is offered by McKinney and } \\
\text { Williams. The governor is advised and authorized to issue Thomas F. McKinney a letter of } \\
\text { appointment as commander of Invincible as a national vessel of war. Volunteers are requested } \\
\text { (Barrett 1836; Telegraph and Register 1836:2). }\end{array}$ & Moctezuma \\
\hline $\begin{array}{l}1836 \\
\text { April } 3\end{array}$ & $\begin{array}{l}\text { According to a Mexican account from Matamoras, the schooner-of-war Bravo, formerly called } \\
\text { Montezuma, commanded by Captain Davis, and schooner Correo Secundo (formerly New } \\
\text { Castle, Captain Watkins) were fitting out to transport troops and supplies for Copano. Correo was } \\
\text { purchased by Mexico and under the command of Captain Thompson. It was armed with two } \\
\text { guns. Lt. Levenue [sic] of cutter Invincible taken prisoner. Pierce's account uses the name Correo } \\
\text { de Mexico instead of Correo Secundo, though these are the same vessel (New Albany Gazette } \\
\text { 1836:2; Pierce 1917:22). Bravo runs aground and is fired into by Invincible (Hall 1835). Captain } \\
\text { Davis of Bravo mentions that his vessel was barely damaged. The Matamoras port official refers } \\
\text { to this vessel as General Bravo (Espino 1835). Zimmerman, a crew member on Invincible, claims } \\
\text { Montezuma's starboard side was stove in (Zimmerman 1836). }\end{array}$ & $\begin{array}{l}\text { Montezuma, } \\
\text { Bravo, } \\
\text { General } \\
\text { Bravo }\end{array}$ \\
\hline $\begin{array}{l}1836 \\
\text { April }\end{array}$ & $\begin{array}{l}\text { According to Dienst, Bravo is one of three Mexican vessels that engaged Independence in a } \\
\text { draw (Dienst 1909a:189). This is likely an error as the Bravo naval action of April } 1836 \text { involved } \\
\text { Invincible (not Independence) and included two and not three navy vessels. }\end{array}$ & $\begin{array}{l}\text { Segundo } \\
\text { Bravo }\end{array}$ \\
\hline $\begin{array}{l}1836 \\
\text { April } 5\end{array}$ & $\begin{array}{l}\text { General Filosola mentions Segundo Correo and Segundo Bravo are ready to leave Matamoras } \\
\text { (Filosola 1849:242). }\end{array}$ & $\begin{array}{l}\text { Segundo } \\
\text { Bravo }\end{array}$ \\
\hline $\begin{array}{l}1836 \text { May } \\
16,17\end{array}$ & $\begin{array}{l}\text { On May 16, a letter sent by Filosola to the commander of Segundo Bravo discusses orders } \\
\text { forwarded to Matamoras on Segundo Correo. Another letter from Filosola on May } 17 \text { mentions } \\
\text { Segundo Bravo and Segundo Correo are to pick up food for the army (Filosola 1849:291-292). }\end{array}$ & $\begin{array}{l}\text { Segundo } \\
\text { Bravo }\end{array}$ \\
\hline 1836 June * & $\begin{array}{l}\text { A summary of governmental expenses for } 12 \text { years ending } 30 \text { June } 1836 \text { mentions both the } \\
\text { schooner Moctezuma and the brig Bravo (Mexico Ministerio de Hacienda 1837). }\end{array}$ & $\begin{array}{l}\text { Moctezuma, } \\
\text { Bravo }\end{array}$ \\
\hline 1836 July & $\begin{array}{l}\text { According to New Orleans papers of July } 1836 \text { Bravo was lost on its way to Veracruz from } \\
\text { Matamoras with all on board except Captain Thompson and two marines (Dienst 1909a:139). A } \\
\text { different account has the lost vessel as Correo Secundo (London Shipping Gazette 1836:1). }\end{array}$ & Bravo \\
\hline $\begin{array}{l}1836 \text { July } \\
20\end{array}$ & $\begin{array}{l}\text { Letter from the office of the Secretary of War and the Navy that mentions a commission for } \\
\text { Thompson for Bravo, payment of the vessel's crew, and also supplies to Matamoras. The } \\
\text { document lists the armament and crew of the squadron of the time consisting of the brigs } \\
\text { Iturbide, Libertador, and Vencedor del Alamo, the brigantine schooner Fama (General Urrea), } \\
\text { schooner Bravo with a } 16 \text { pounder pivot gun and four } 9 \text { pounder carronades. Bravo has a crew of } \\
60 \text { with } 10 \text { soldiers and a garrison sergeant. This also mentioned two vessels being purchased } \\
\text { from the Yucatan: General Terán and the schooner Hidalgo and two } 50 \text { horsepower steamboats } \\
\text { that are armed each with a } 16 \text { pounder (Secretaria de Guerra y Marina 1836). }\end{array}$ & Bravo \\
\hline $\begin{array}{l}1836 \\
\text { August }\end{array}$ & $\begin{array}{l}\text { "The Mexican Fleet consisting of the brig Fama and the schooner Bravo were at Vera Cruz on } \\
\text { the 9th [August 1836]- they were preparing to make a cruise" (Boston Morning Post [BMP] } \\
\text { 1836:2) }\end{array}$ & Bravo \\
\hline $\begin{array}{l}1837 \text { Feb } \\
11\end{array}$ & $\begin{array}{l}\text { Naval schooner Bravo with the infamous Capt. Thompson arrived at Sisal to take General Toro } \\
\text { on board - he was being removed as commander general of Yucatan. Thompson went } 10 \\
\text { leagues inland to the capital "Menda" (sic, Mérida) (BMP 1837a:2). }\end{array}$ & Bravo \\
\hline
\end{tabular}




\section{Table 1. Timeline Summary of the Various Vessels by the Names of Ariel, Bravo, General Bravo, Montezuma, and Moctezuma}

\begin{tabular}{|c|c|c|}
\hline Date & Event & Names \\
\hline $\begin{array}{l}1837 \\
\text { April } 12- \\
16\end{array}$ & $\begin{array}{l}\text { USS Natchez engages General Urea, General Terán, and Bravo at Brazos Santiago in dispute } \\
\text { over detained US schooners (Hill 1987:70-71). }\end{array}$ & Bravo \\
\hline $\begin{array}{l}1837 \\
\text { April } 9-17 \\
1837 \text { July } \\
9\end{array}$ & $\begin{array}{l}\text { Bravo "practically blocked" in mouth of Rio Grande during the Natchez engagement-this was } \\
\text { likely Brazos Santiago and not at the Rio Grande River (Hill 1987:71). } \\
\text { Report that Captain Thompson and his lieutenant deserted Bravo and were headed in an open } \\
\text { boat northward towards Texas from Mexico (BMP 1837b:2). }\end{array}$ & $\begin{array}{l}\text { General } \\
\text { Bravo }\end{array}$ \\
\hline $\begin{array}{l}1837 \\
\text { Aug. }\end{array}$ & In Veracruz harbor with General Terán and Independence (Hill 1987:87). & $\begin{array}{l}\text { General } \\
\text { Bravo }\end{array}$ \\
\hline $\begin{array}{l}1838 \text { Aug } \\
28\end{array}$ & $\begin{array}{l}\text { General Bravo is part of a flotilla that arrives at Campeche that also includes Fama and Vencedor } \\
\text { del Alamo (Bonilla 1946:118). }\end{array}$ & $\begin{array}{l}\text { General } \\
\text { Bravo }\end{array}$ \\
\hline $\begin{array}{l}1842 \\
\text { April }\end{array}$ & $\begin{array}{l}\text { Being built by Greens and Wigrams in England. A heavy-timbered wooden vessel with } 1111 \text { tons } \\
\text { displacement, mounting one Paixhan 68-pounder, two long 32's, four 32-pounder carronades, } \\
\text { and a small 9-pounder (Hill 1987:172-173). }\end{array}$ & Moctezuma \\
\hline $\begin{array}{l}1843 \\
\text { April } 30\end{array}$ & $\begin{array}{l}\text { Battle with Austin and Wharton off Campeche. Commander and twenty crew members of } \\
\text { Moctezuma killed. The Mexican fleet withdrew (Hill 1987:183-188). }\end{array}$ & Moctezuma \\
\hline $\begin{array}{l}1843 \text { May } \\
16\end{array}$ & Second engagement with Austin and Wharton. Mexican fleet defeated (Jordan 2006:263-261). & Moctezuma \\
\hline 1846 & Repossessed by England for failure of payment (Scheina 1969:262). & Moctezuma \\
\hline
\end{tabular}

*yellow background color indicates row where more than vessel is mentioned. 


\section{The First Bravo (1825-ca. 1835)}

The first documentation of a Mexican naval vessel of this name occurs in the mid-1820s. It was one of three vessels purchased from England in 1824, soon after Mexico's independence (Bonilla 1946:82; Bidwell 1960:331). It was originally the 322 27/94 brig-rigged yacht Ariel, built on the Thames River in 1824 and registered in London to the Earl of Harborough (Bidwell 1960:331; von Mach, personal communication 2017; von Mach, personal communication 2018). It likely arrived in Mexico in the fall of 1825, in close proximity to the delivery of Victoria in August and Avend Prindien (renamed Libertad) in September (Bonilla 1960:349). In 1825, Aerial, renamed Bravo, was one of several naval vessels protecting San Juan De Ulúa, an island fortification off Veracruz (Bonilla 1946:98). In 1826, U.S. Captain David Porter abandoned his commission in the U.S. Navy to serve as the Commodore for the Mexican Navy. This brig was part of the Mexican fleet when he took command.

In his memoir, Commodore Porter's son David Dixon Porter, a midshipman in the Mexican Navy, recollected Bravo as having 14 24-pounder carronades when first inspected by his father at Veracruz in 1825 (Porter 1875:352; Long 2014:265). Other accounts list 18 guns, which seems to be the most consistently described armament, and 20 carronades (New Times 1827:2; Bidwell 1946:444; Bonilla 1946:98). In late December 1826, Porter relocated his Mexican fleet to the Florida Keys as a staging area and temporary headquarters for his planned offensive to capture Spanish vessels off Cuba. Libertad, Victoria, and Bravo soon began seizing prizes and in retaliation Spanish forces blockaded the Mexican fleet at Key West. Porter's vessels were successful in dodging the blockading vessels and ultimately captured 21 prizes while stationed in the area (Ward 1828:307-308; Bonilla 1946:102; Viele 1999:105-106). The Mexican Navy's activities at Key West challenged U.S neutrality and interfered with regional trade between the U.S. and Cuba. When President John Quincy Adams signed a bill prohibiting prizes from entering Key West (and thus selling their goods) Porter's principal means of paying his crews was quelled. After a tenure of five months in the keys, Porter's fleet traveled to New Orleans to collect the newly acquired Mexican brig Guerrero and to solicit crew before returning to Veracruz (Viele 1999:114-115).

\section{The Armed Mexican Transport Montezuma (1832)}

While the brig Bravo was still in use, a schooner of the name Montezuma entered the scene. In early August 1832, under the command of Captain Pedro Villareal, the armed schooner Montezuma detained and robbed the U.S. schooner William A. Turner near Mataznas, Cuba. (British Traveler and Commercial and Law Gazette 1832:2; Niles Weekly Register 1832:82-83). It was 
armed with 3 cannons, one of which was a heavy pivot gun (Jones 1878:39). Later in October, the U.S. schooner-of-war Grampus captured Montezuma off Tampico in retaliation for its action against William A. Turner. When it was captured, Montezuma was being used as a troop transport and carried 40 soldiers in addition to a crew of 36. It was adjudicated at New Orleans (Washington National Intelligencer 1832:3; Jones 1878:39-41).

The U.S. government learned that the vessel was not an official Mexican naval schooner but instead had been unlawfully outfitted as an armed vessel by military officers, including Santa Anna, as part of an uprising against the Mexican government. Mexico requested the vessel be turned over to their consul. This was denied in October 1832, on the grounds that it was not an official vessel of the Mexican government and had engaged in an act of piracy (Livingston 1832; Montoya 1832). On October 1, 1832 it was condemned by the U.S District Court and sold; it was renamed Annette and registered the following month at New Orleans under new owner Alexander Baron and master Henry L. Thompson, later Commodore of the Texas Navy. According to its registration, Annette was $6137 / 95$ tons $17.32 \times 5.43 \times 2.16 \mathrm{~m}(56.83 \times 17.83 \times 7.08 \mathrm{ft})$ and was described as having one deck, two masts, a square stern, and plain head (Survey of Federal Register 1942:9; von Mach, personal communication 2018).

During this same period, in 1833, author Juan de Dios Bonilla (1946:118) describes a schooner named Montezuma, under the command of Don Tomas Marin, as transporting troops to Matamoras and then New Orleans in November. It is unclear if this vessel is the recently captured schooner with inaccurate historic information regarding the later transport dates or if another ship with this name is also being used in this capacity since Montezuma's capture.

\section{The New Threat Moctezuma/Montezuma, Alias Bravo/General Bravo (1834-1836)}

On May 3, 1835 a vessel referred to as both Moctezuma and Montezuma seized the New Orleans schooner Martha at Galveston Bay and brought it to Veracruz. First Lieutenant John Calva of Montezuma was accredited with the capture (Washington Globe 1835:2). Days later, in letters dated May 7 and 18, the Mexican commander at Anahauc, Antonio Tenoria, commented on the arrival of Moctezuma with troops and money and mentioned that some of the passengers did not have passports (Tenoria 1835a; 1835b). These May 1835 accounts are an early indication of activity by a new vessel bearing this name. Moctezuma appears to have been variably called Montezuma, Bravo, General Bravo, and possibly Segundo Bravo throughout the following years.

Is this schooner Moctezuma the former brig Bravo or an altogether new vessel? Less is known of the activities of the brig Bravo during these years with no references to it discovered by the author 
after 1836. At this juncture, the brig Bravo and schooner Moctezuma briefly coexist and are both listed in the official summary of naval expenses for the 12 years ending in 1836 (Mexico Ministerio de Hacienda 1837). Author Robert Scheina (1970:47) mentions that the schooner Moctezuma was already part of the navy when new vessels were acquired in 1835. This is likely based on an 1857 history of Veracruz (Lerdo de Tejada 1857:417) that states Porter's navy of 1829 was all but gone by 1835 except for the schooner Moctezuma and the brig Veracruzana. Scheina and Lerdo de Tejada can only be referring to the brig Bravo and not the schooner Moctezuma, as a schooner of this latter name seems to first occur in 1834 and does not appear to part of the 1820 s fleet. At this time, the brig Bravo would have been in Mexican service for a decade following its use in England-it may have been retired at this time and placed in ordinary. Interestingly Mexican accounts refer to the new schooner as Moctezuma, whereas U.S. and Texas accounts often, possibly mistakenly, call this vessel Montezuma. In the following discussion, Moctezuma will be used.

A newspaper article from 1834 reports the arrival of the schooners of war Moctezuma and Consolation (79 tons) and the 111-ton pilot-boat schooner Correo de Tampico, with the navy on April 17. Consolation and Correo de Tampico had crews of 11 and 8 men respectively (Procurador del Pueblo 1834; von Mach, personal communication 2018). According to the Memoria del secretario de estado y del despacho de la guerra published in Mexico in 1834, Moctezuma was armed with one 12-pounder culebrina and two 8-pounder cannons; it had four officers and a crew of 33 men. It had recently been outfitted at New Orleans (von Mach, personal communication 2018).

In late 1835 Moctezuma began regularly cruising the coast from the Rio Grande River to Galveston and into Galveston Bay, alarming revolutionary leaders. Texas had yet to declare its independence (the following March) so undeniably Mexico recognized the escalation in hostilities and the undisguised movements to both supply Texian volunteers and enlist privateers as unlawful actions. The "new" schooner Moctezuma became an immediate threat to Texas and U.S. commerce along the Texas coast as it attempted to deter revolutionary activities and prevent the shipment of contraband supplies to Texas. The presence of Moctezuma, and to a lesser extent Veracruzano, were a direct influence on the formation of the Texas Navy of 1836.

In June, Moctezuma, under the command of Lieutenant Calvi, was fired upon by the U.S. revenue cutter Ingham, though there is a debate as to which vessel fired the first shot. The revenue cutter was stationed off Texas to monitor perceived threats against American shipping by Mexico, aggravated by Moctezuma's capture of Martha earlier in March. The "clipper-built schooner" Moctezuma was sighted off Brazos Santiago on June 14 and, by American accounts, quickly approached Ingham and opened fire. This shot was also interpreted as a "signal" to the revenue 
cutter. Moctezuma retreated, jettisoning heavy items as to lighten its load to cross the bar. The two vessels continued to exchange fire until Calvi inadvertently ran his vessel upon the bar. Captain Jones of Ingham decided not to sink the damaged Moctezuma as it lay grounded (Wells 1998:469472). A newspaper summary of this engagement described Moctezuma as having four guns and a crew of 24 (London St. James Chronicle and General Evening Post 1835:4).

In October, the now-recovered Mexican schooner reportedly fired a shot at the town and fort of Velasco (McKinney and Williams 1835a) and in November it chased, ran aground, and captured the U.S. schooner Hannah Elizabeth with a contraband cargo of arms at Pass Cavallo (Fannin 1835; Fisher 1835). Moctezuma then indirectly caused the Texan privateer San Felipe to run around on Matagorda Peninsula before later approaching and firing into it (Fleury 1874; Wilson 1874).

Talks began immediately to formally create a navy to counter this activity. On November 9 , Thomas McKinney was reported to be fitting out a vessel to pursue Moctezuma (McKinney 1835a). Days later, commissions (for privateers) were requested to protect the coast from Montezuma and Vera Cruzana (General Council 1835:8). On January 8, Invincible was offered by McKinney to serve in the new navy and the governor was additionally authorized to issue McKinney a letter of appointment as commander of the schooner as "a national vessel of war" (Barrett 1836). On January 9, volunteers were requested, likely to man the vessel, in pursuit of Moctezuma and on the 11th the purchase of the warship was officially announced (McMullen 1836; Telegraph and Register 1836:2). Other navy purchases would soon follow in January including Brutus, the former revenue cutter Ingham now called Independence, and the former privateer William Robbins-newly rechristened Liberty (Powers 2006:52-53). The captain and crew of Invincible felt it was their mission to capture the elusive Moctezuma and searched in vain for sight of it.

By April, historic accounts show that Moctezuma/Montezuma was renamed Bravo and under the command of Captain Fernando Davis. It was in convoy with the newly purchased two-gun schooner of war Correo Secundo (commanded by infamous Captain Thomas M. Thompson) preparing to transport troops and supplies to Copano in preparation for a Mexican military advance against the revolutionary Texians. Bravo and Correo Secundo were at Brazos Santiago, the ocean-port for the river-town of Matamoros, located $88.5 \mathrm{~km}(55 \mathrm{mi})$ up the Rio Grande River. This river emptied in the Gulf of Mexico at a location approximately $12.9 \mathrm{~km}$ (8 mi) southwest of Brazos Santiago Pass. Before regular steam navigation, goods intended for Matamoros were shipped to the harbor at Brazos Santiago and then transported overland via two beach roads accessible at low tide. Scow barges carried passengers and freight to the mainland during high tide 


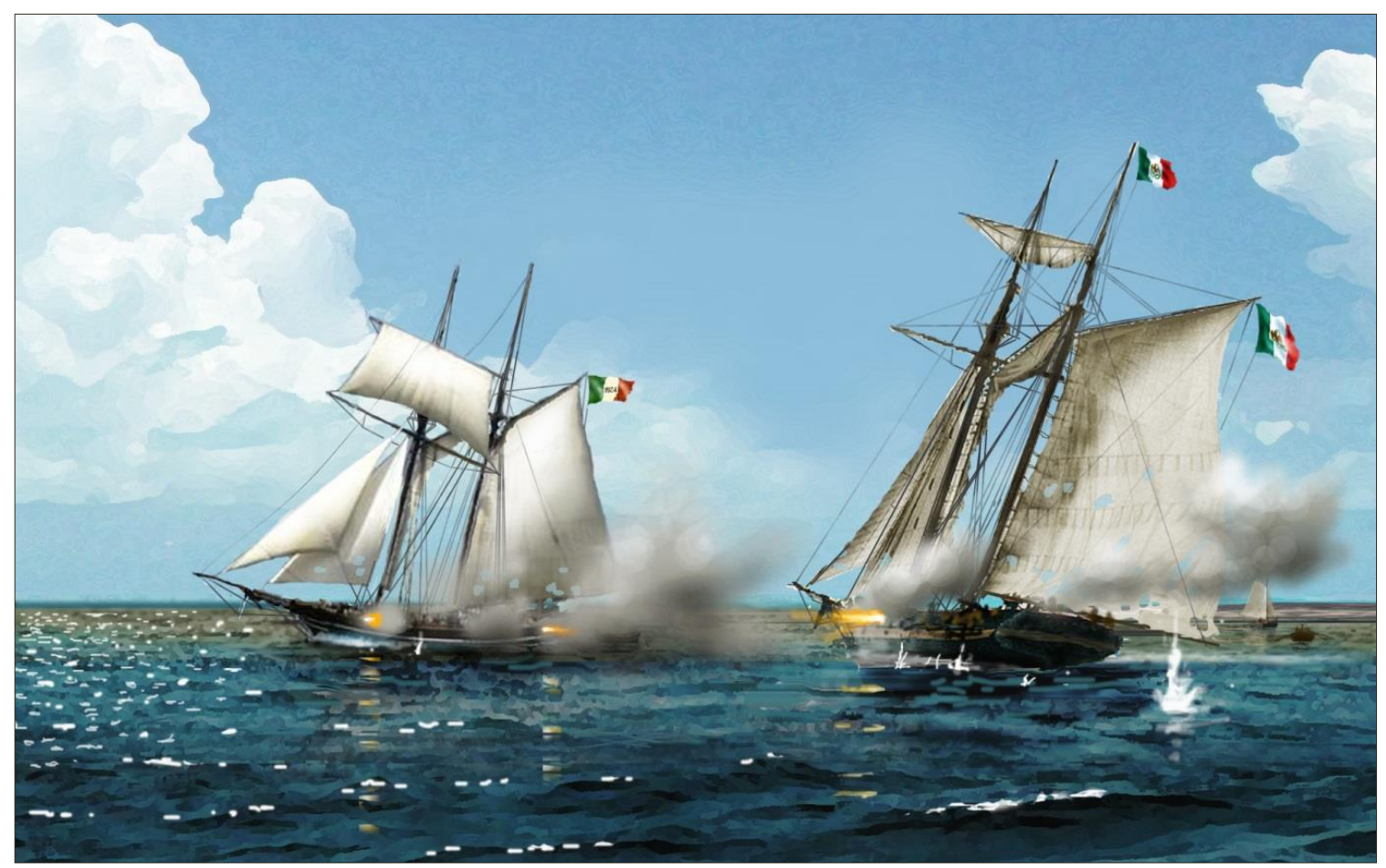

Figure 9. Engagement off Brazos Santiago, April 3, 1836; Invincible vs. Bravo by Peter Rindlisbacher (2017).

and flooding (Powers 2006:77-78). It is at this point in history that Invincible encounters Bravo after three months of searching. What happens next is still debated.

The bare and undisputed facts of the case are thus: Bravo is unattended (Correo was likely anchored in the harbor) and in the process of repairing its rudder that became damaged on the bar. Captain Thompson from Correo is helping with the rudder replacement. Invincible, flying American colors, approaches the vessel and immediately recognizes it as its nemesis Moctezuma/Bravo. Officer Living convinces Captain Jeremiah Brown, against his better judgment, to allow him to proceed to Bravo in disguise as a U.S. revenue officer as a means to gain intelligence on Mexican activities. Living is taken by ship's boat to Bravo and is secured on board while Bravo sends its launch with Captain Thompson to Invincible to confirm Living's papers. Captain Brown recognizes Thompson and fires upon the launch and then at Bravo once the Mexican Navy has moved Living to shore. Bravo attempts to retreat but without a working rudder runs further aground on the bar and is fired upon by Invincible (Figure 9). During the engagement Invincible notices the approaching brig Pocket and leaves in pursuit-Pocket is captured and taken by Invincible to Galveston.

The main Mexican account of this transaction offers a slightly different perspective on Invincible's departure from the battle-described as an actual retreat as opposed to a change in Invincible's military priorities (the Texian version of events), i.e. capturing an unknown brig three 
to four miles distant instead of irrefutably sinking Bravo. Captain Davis of Bravo, in his report to Jose Maria Espino, the captain of the port of Matamoros, acknowledged that Bravo was vulnerable as it lay aground on the bar, but described Invincible as retreating due to reinforcements in the form of the approaching armed Correo and the adjusted position of the land artillery (Espino 1836). Perhaps Jeremiah Brown felt that Invincible, in its slightly damaged condition, was more capable of capturing an unarmed brig as opposed to prolonging an armed engagement with Correo, Bravo with its pivot cannon, and shore artillery.

Two important facts of this event are heavily disputed: where this engagement occurred and if Bravo sank. Differing eyewitness and second-hand accounts of the "battle" are presented in Table 2 , in chronological order of the historic report. Most often the early accounts place this naval exchange at Brazos Santiago wherein later post-19th-century authors instead place this at the mouth of the Rio Grande River. This may be, in part, due to misunderstanding Texas geography and perhaps not recognizing that Matamoros' ocean port at this time was not at the river mouth but 8 mi. further northeast at Brazos Santiago Harbor and Pass. Some reports mention artillery firing upon Invincible and this, in itself, decidedly places the event at Brazos Santiago near the Mexican garrison. Living was also tried as a spy and executed at Brazos Santiago, and not Matamoros (Pierce 1917:22; Powers 2006:78-81), which lends additional credence to this location as the site of the battle. Finally, Brown, Invincible's captain, explicitly states Pocket was captured off Brazos Santiago which should leave no room for doubt (Brown 1836).

Whether or not Bravo actually sank is more difficult to solve. U.S. and Texian eyewitness accounts and newspapers typically describe Invincible as prevailing in this incident with Bravo "sinking," "wrecked by a broadside," and "gone to pieces" (Table 2). Some newspaper reports do not describe the outcome - only that Bravo ran aground. Not so coincidentally, a Mexican account claims Bravo was largely uninjured and merely suffered a cannon shot to the poop (stern deck) and minor damages to the rigging (Espino 1836; Hill 1987:51-52). The captain sought to get the vessel off the bar, but a curious comment in the letter suggests Bravo may have been taking on water (Espino 1836). The mystery only deepens as a sailing vessel by the name Bravo continues to serve an active role in the Mexican Navy until 1838 - more than a year after its "sinking." The author reviewed a Bravo logbook in the collection of the Briscoe Center for American in Austin, TX (Añorga 1835), but unfortunately the last entry dates to December 1835, many months before the events on the Texas coast. 
Table 2. Accounts of the Sinking of Bravo.

\begin{tabular}{|c|c|c|c|}
\hline Source & Account Summary & Location* & Demise \\
\hline $\begin{array}{l}\text { William Gray } \\
1836 \\
(1909: 154- \\
155)\end{array}$ & $\begin{array}{l}\text { According to his diary account of April 7, 1836, William Gray was on board Brutus } \\
\text { when it was approached by Invincible just returning from Brazos Santiago with the } \\
\text { prize Pocket. Gray was told that when Invincible encountered Montezuma, "now } \\
\text { called Bravo," both Davis and Thompson were on board. Bravo was run aground } \\
\text { and "disabled" and could not be boarded due to the shallow waters and the } \\
\text { presence of } 1000 \text { Mexican troops on the beach. The account mentions that Lt. } \\
\text { Living was left on board Bravo but that the crew of the waiting launch took off } \\
\text { when the action began. This occurred on April } 3 \text { which was Easter. }\end{array}$ & BS & Disabled \\
\hline $\begin{array}{l}\text { Walter } \\
\text { Zimmerman } \\
1836\end{array}$ & $\begin{array}{l}\text { Walter Zimmerman, who had been part of General Mexia's expedition to Tampico, } \\
\text { enlisted as crew on Invincible. He described Montezuma as being superior in men } \\
\text { and guns. According to Zimmerman, after a conflict of } 2 \text { hours the "enemy went } \\
\text { down with his larboard side entirely stove in." It pursued a merchant brig [Pocket] } \\
\text { after Montezuma sank, thinking it was an armed 18-gun vessel. There are } \\
\text { problems with this source as Invincible had more crew and almost twice as many } \\
\text { cannons. }\end{array}$ & - & Sunk \\
\hline $\begin{array}{l}\text { Newspaper } \\
\text { Account } \\
1836 \\
\text { (reprinted in } \\
\text { Dienst } \\
\text { 1909b:253) }\end{array}$ & $\begin{array}{l}\text { This account mentions that Invincible approached the Mexican brig [Bravo] and } \\
\text { made an inquiry then sent a boat out to meet it. Invincible exchanged gunfire with } \\
\text { the Mexican vessel [Bravo] "which fired several guns each" - the schooner with } \\
\text { the Mexican flag bore away towards shore and "the other vessel [Invincible] } \\
\text { tacked ship and stood for his brig [Pocket], she being about three or four miles } \\
\text { distant." }\end{array}$ & BS & Retreated \\
\hline $\begin{array}{l}\text { Covington } \\
\text { Western } \\
\text { Constellation } \\
(1836: 2)\end{array}$ & $\begin{array}{l}\text { "The Texian armed schooner Invincible, Captain Brown, fell in with the Mexican } \\
\text { schooner Montezuma, at anchor off the Brasos Santiago. An action immediately } \\
\text { took place, with a running fight of several hours, which terminated in the sinking of } \\
\text { the Montezuma, before she reached the shore to which she was running. When } \\
\text { last seen her yards were underwater. She was preparing to convey to Galveston } \\
\text { Bay about two thousand men the expedition is now destroyed. The Invincible was } \\
\text { somewhat cut in her sails and rigging but had not a man wounded. The fate of the } \\
\text { Montezuma crew is not known." }\end{array}$ & BS & Sunk \\
\hline $\begin{array}{l}\text { London } \\
\text { Morning } \\
\text { Post } \\
(1836: 5)\end{array}$ & $\begin{array}{l}\text { "A naval engagement between the Mexican schooner Montezuma, and the Texian } \\
\text { schooner Invincible, off the Brasos [sic] de Santiago, is reported to have taken } \\
\text { place, which terminated, after a running fight of several hours duration, in the } \\
\text { sinking of the former." }\end{array}$ & BS & Sunk \\
\hline $\begin{array}{l}\text { Jose Maria } \\
\text { Espino } 1836\end{array}$ & $\begin{array}{l}\text { The captain of the port of Matamoras (Espino) relays information forwarded by } \\
\text { Bravo's Captain Fernando Davis. While they were repairing Bravo's rudder, an } \\
\text { American vessel approached and an officer from an American vessel came } \\
\text { aboard Bravo wanting to communicate with the port. He describes the vessel } \\
\text { [Invincible] as firing upon Thompson in the launch and also at Bravo. Levine [sic] } \\
\text { was taken prisoner once they were attacked [by Invincible]. Bravo only sustained } \\
\text { a shot to the stern and damage to the rigging. The battle lasted over an hour and } \\
\text { was cut short when the vessel left in pursuit of another brig. The letter implies that } \\
\text { the approach of Correo and firepower from the beach encouraged the retreat of } \\
\text { the warship [Invincible]. }\end{array}$ & BS & $\begin{array}{l}\text { Afloat and } \\
\text { aground on } \\
\text { the north } \\
\text { side of the } \\
\text { bar - only } \\
\text { a shot to } \\
\text { the stern }\end{array}$ \\
\hline $\begin{array}{l}\text { Edward Hall } \\
\text { (Powers } \\
2006: 80 \text { ) }\end{array}$ & $\begin{array}{l}\text { Ed Hall was informed by an eyewitness that "the Montezuma is on the bar and so } \\
\text { injured as to be abandoned: her guns taken on shore and put on other vessels." }\end{array}$ & - & Abandoned \\
\hline
\end{tabular}


Table 2. Accounts of the Sinking of Bravo.

\begin{tabular}{|c|c|c|c|}
\hline Source & Account Summary & Location* & Demise \\
\hline $\begin{array}{l}\text { General } \\
\text { Filosola } \\
1836 \\
(1849: 242, \\
290-292)\end{array}$ & $\begin{array}{l}\text { Reported on April } 5 \text { that Segundo Bravo and Segundo Correo are completely } \\
\text { prepared to leave Brazos Santiago. }\end{array}$ & BS & Active \\
\hline $\begin{array}{l}\text { Morning } \\
\text { Chronicle } \\
\text { (1836a:4) }\end{array}$ & $\begin{array}{l}\text { "The Texian armed schooner Invincible fell in with the Mexican schooner } \\
\text { Montezuma, off the Brasos Santigo [sic]; an action took place, which terminated in } \\
\text { the sinking of the Montezuma." }\end{array}$ & BS & Sunk \\
\hline $\begin{array}{l}\text { David } \\
\text { Conrad } 1836 \\
\text { (Powers } \\
2006: 80 \text { ) }\end{array}$ & Bravo, after grounding had gone to pieces in the breakers. & - & $\begin{array}{l}\text { Broken } \\
\text { Apart }\end{array}$ \\
\hline $\begin{array}{l}\text { Rueben } \\
\text { Potter } 1836 \\
\text { (Powers } \\
2006: 80)\end{array}$ & $\begin{array}{l}\text { "Bravo sank more quickly that was would have been expected from a mere } \\
\text { thumping." }\end{array}$ & - & Sunk \\
\hline $\begin{array}{l}\text { Hayes }(1974 \\
[1879]: 146)\end{array}$ & $\begin{array}{l}\text { Invincible encountered Montezuma while cruising off Brazos Santiago and after a } \\
\text { two-hour engagement Montezuma "was driven ashore and left in a sinking } \\
\text { condition." Hayes incorrectly has the captain of Montezuma as Thompson and } \\
\text { that Invincible returned to Galveston for repairs after the conflict and before } \\
\text { capturing Pocket-both points disagree with other accounts. }\end{array}$ & BS & Sinking \\
\hline $\begin{array}{l}\text { Bancroft } \\
(1889: 272)\end{array}$ & $\begin{array}{l}\text { Invincible crippled Bravo and drove her ashore. Invincible only had injured rigging } \\
\text { which was repaired. Invincible went in pursuit of Pocket. }\end{array}$ & - & Crippled \\
\hline $\begin{array}{l}\text { Dienst } \\
\text { (1909b: 252- } \\
\text { 253) }\end{array}$ & $\begin{array}{l}\text { Bravo loses rudder crossing the bar at the mouth of the Rio Grande River. It ran } \\
\text { aground near the north beach and was wrecked by a broadside from Invincible. } \\
\text { Dienst's account disagrees with his use of a direct quote from a newspaper article } \\
\text { that says this exchange occurred at Brazos Santiago. }\end{array}$ & RG & Wrecked \\
\hline $\begin{array}{l}\text { Fischer } \\
\text { (1976:133- } \\
\text { 134) }\end{array}$ & $\begin{array}{l}\text { Account mentions Bravo losing its rudder crossing the bar and that Leving [sic] } \\
\text { came aboard. Because the vessel could not be steered it ran aground. Mentions a } \\
\text { brief engagement and that Bravo was put out of action by a broadside. Leving and } \\
\text { the crew went ashore. The engagement interrupted by the arrival of Pocket. }\end{array}$ & RG & $\begin{array}{l}\text { Put out of } \\
\text { action }\end{array}$ \\
\hline $\begin{array}{l}\text { Pierce } \\
(1917: 22)\end{array}$ & $\begin{array}{l}\text { Invincible arrives at the port of Brazos Santiago and encounters General Bravo } \\
\text { and Correo de Mexico with food supplies for Mexican troops near Copano. Livine } \\
\text { [sic] sent aboard General Bravo seeking to go ashore to speak to the American } \\
\text { Consul of Matamoras. Invincible fired upon Bravo when Bravo's launch } \\
\text { approached without Levine [sic] present. Bravo returned fire, Correo got under } \\
\text { sail to attack Invincible, and Mexican shore artillery fired upon Invincible. } \\
\text { Invincible retreated towards the bar or pass. }\end{array}$ & BS & Aground \\
\hline
\end{tabular}


Table 2. Accounts of the Sinking of Bravo.

\begin{tabular}{|c|c|c|c|}
\hline Source & Account Summary & Location* $^{*}$ & Demise \\
\hline $\begin{array}{l}\text { Hill } \\
\text { (1987:51- } \\
52)\end{array}$ & $\begin{array}{l}\text { Bravo at the mouth of the Rio Grande River with Correo Segundo in convoy. Lost } \\
\text { its rudder and attacked by Invincible. After an hour in the engagement, the brig } \\
\text { Pocket spotted and Invincible leaves in pursuit. Thomas Thompson was on Bravo } \\
\text { helping with the replacement of a new rudder. Lt Leving [sic] went on board Bravo } \\
\text { and Thompson was sent in a boat to Invincible to make arrangements to have } \\
\text { Leving [sic] go ashore. Invincible's Captain Brown recognized Thompson and let } \\
\text { him come aboard and imprisoned him below deck (this disagrees with other } \\
\text { accounts) and fired a broadside. No injuries to Bravo other than a round shot to } \\
\text { the poop and two minor injuries to the rigging. The battle was cut short when } \\
\text { Invincible left in pursuit of Pocket. Hill's account paraphrases Espino's report to } \\
\text { some extent but changes details (see above). }\end{array}$ & RG & $\begin{array}{l}\text { Barely } \\
\text { injured }\end{array}$ \\
\hline $\begin{array}{l}\text { Powers } \\
\text { (2006:78- } \\
81)\end{array}$ & $\begin{array}{l}\text { Invincible, flying American colors, recognized and approached Bravo. It was } \\
\text { commanded by Fernando Ricardo Davis, an American that started as a } \\
\text { midshipman in the Mexican Navy in 1823. Living dressed in a revenue cutter's } \\
\text { uniform and was taken to Bravo. Thompson on board Bravo believed the } \\
\text { unknown vessel to be Invincible. Capt. Davis sent Thompson on a sloop-rigged } \\
\text { harbor boat over to Invincible to verify Living's story. He recognized Captain } \\
\text { Brown and reversed course and Brown fired upon Bravo. Invincible's boat was } \\
\text { released (though Living was taken ashore) and at this point Invincible fired into } \\
\text { Bravo as it was trying to get underway without its rudder. Bravo "lodged on the } \\
\text { bar, where a few shots from Invincible filled her with water" Bravo fired return } \\
\text { shots and was abandoned. }\end{array}$ & BS & Abandoned \\
\hline $\begin{array}{l}\text { Jordan } \\
\text { (2006:52- } \\
53)\end{array}$ & $\begin{array}{l}\text { General Bravo and Segundo Correo Mexicano stood guard at the mouth of the } \\
\text { Rio Grande to keep news of the impending Mexican invasion from leaving } \\
\text { Matamoras. They were to meet John M. Brandel, New Castle, and Pocket with } \\
\text { their respective supplies to convoy them to Matagorda Bay. Invincible sights } \\
\text { Bravo and Correo off Brazos Santiago, at the mouth of the Rio Grande, and } \\
\text { recognized Bravo as having a damaged rudder. Eventually an hour or so gun } \\
\text { battle ensues, Bravo runs aground at the river's mouth. Invincible captures } \\
\text { Pocket. }\end{array}$ & RG & $\begin{array}{l}\text { Run } \\
\text { aground }\end{array}$ \\
\hline
\end{tabular}

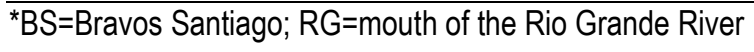




\section{The Bravo and Segundo Bravo Puzzle (1836-1838)}

In spite of Texian confidence in the loss of Bravo at the hands of Invincible's gunfire, Bravo appears later in 1836-1838 now under the command of Captain Thompson, formerly of Correo Mexicano/Segundo Correo. The author is grateful to colleague John Powers (2006) for being the first author encountered during research to question the veracity of the differing battle accounts and to acknowledge the disparity between the wrecked and surviving versions of Bravo after April 1836. His work was revisited in preparation for this study. Unless an extremely informative letter(s) is discovered, this mystery may never be satisfactorily resolved. Though it seems the evidence weighs more heavily towards the complete irreparable loss of Bravo, there is also evidence that suggests it did not, in fact, sink.

After the "sinking" of Bravo on April 2nd, later on May 17, it was reported that "Segundo Bravo" and "Segundo Correo" were at Brazos Santiago to pick up supplies for the army at Copano Bay (Filosola 1849:290-291). There were other earlier Filosola communications from April 5 and May 16 in regard to both vessels. Powers (2006:n. 37, 247-248) suggested that Segundo Bravo may indicate a replacement warship as an explanation for the disparity between these reports, the problematic timeline of the Invincible engagement, and the reference to the Mexican warship as the "second" Bravo.

An alternative explanation for "Segundo," however may simply be that the 1835 schooner Moctezuma became the "second" Bravo when it was renamed later that year, since the brig Bravo was already a recognized commissioned naval vessel. The use of "Segundo" does not necessarily imply a substitute schooner-of-war by that name-which would technically have been a third, and not second, vessel of the name Bravo to serve the Mexican government. It could have instead been a convenient way to differentiate between the schooner and the earlier brig.

In his report to Fernando Fernandez, Commandant of the Department of Nuevo Leon and Tamaulipas, the commander of Matamoros, Jose Maria Espino, relays the account of the naval engagement. This information had been provided by Captain Fernando Davis of Bravo. Two key passages allude to the condition of the vessel: (a) the statement that Bravo was barely injured only having sustained a shot to the stern with two crew injured by a broken pulley and (b) that Bravo was aground on the north side of the bar awaiting a strong wind; they were working on saving the vessel though it was taking on water (Espino 1836). The eyewitness report to Edward Hall (Powers 2006:80) indicating the guns were removed from Bravo does not necessarily mean they were being salvaged from the presumed wreck and placed on other vessels. This action was the typical measure 
taken to lighten a grounded vessel so that it could be refloated by removing heavy items such as guns, cargo, and ballast. The cannons may have only been temporarily relocated with the intent to replace them on Bravo later. The Espino (1836) report showing that Bravo had a pivot cannon and broadside guns is consistent with the armament described on the later still-active Bravo in July 1836.

Curiously, historian Alex Dienst (1909a:139) in his early works on the Texas Navy references accounts from an unnamed July 1836 New Orleans newspaper claiming Bravo sank on its way from Matamoras to Veracruz with the loss of all on board except Thompson and two marines. Perusal of the New Orleans Bee for July failed to relocate such an article, but a similar account from the New York Courier and Enquirer (reprinted in the September London Shipping Gazette 1836:1) describes the exact same event, excepting that this misfortune instead befell Correo Secundo. Considering Thompson at this time was the commander of Correo Secundo (Segundo) and not Bravo, this latter account is perhaps more compelling and believable.

It is tempting to consider if Thompson, upon his return to Veracruz without a ship to command, was made captain of the refloated Bravo; however, the other option would be that he was given command of an altogether different vessel rechristened Bravo. Letters in the Mexican archives from July 1836 discuss Thompson as commander of the schooner Bravo (Figure 10a) and also summarizes it arms and crew as part of a larger discussion of naval affairs (Figure 10b, 10c) including a list of the crew and armament of all current navy vessels. Bravo, as described in a document dated July 20, was armed with a 16-pounder pivot cannon and four 9-pounder carronades. The 16-pounder is not a commonly recognized cannon "caliber" and may be the error of the original document's author. Bravo, Hidalgo and two other gunboats were described as having 16-pounder cannon. A copy of the same document also describes the Bravo pivot gun as 16pounder. Bravo had a crew of 60 including 10 soldiers and a garrison sergeant (Reibaud 1836; Secretaria de Guerra y Marina 1836). Is this an altogether different vessel than the previously described Bravo of four guns and a crew of 50 (London St. James Chronicle and General Evening Post 1835:4), with the additional pivot gun mentioned by Captain Fernando (Espino 1836)? This is difficult to say, especially with the misidentifications and errors occurring in the historic sources.

In August 1836, Bravo and the brig Fama (also called General Urrea) were preparing to disembark from Veracruz on a cruise (BMP 1836:2). Later in February 1837 Captain Thompson transported General Sayas on Bravo to Sisal to replace General Toro as the commander general of the Yucatan (BMP 1837a:2). Bravo was also involved in what was considered a scandalous incident at Brazos Santiago in April 1837 which resulted in an exchange of cannon fire between vessels of the U.S. and Mexican navies. The U.S. merchantmen Champion and Louisiana had been 
detained at Brazos Santiago and the U.S. Navy intervened to secure their release. USS Natchez arrived at Brazos Santiago and left in convoy with Louisiana.

Upon returning for Champion, Natchez encountered the Mexican fleet consisting of General Urrea, General Teran, and Bravo. Without provocation Natchez captured General Urrea on April 16 and was fired upon by both Bravo and the port artillery but both were at too great a distance to have an effect. A shot however did accidentally strike the U.S. merchant vessel Climax. This was viewed by Mexico as hostile action by the United States. Commodore Dallas of the U.S. Navy, with a fleet of five vessels including USS Constellation, traveled to Veracruz to deliver a formal apology to the Mexican government (Pierce 1917:23-24; Hill 1987:70-71). General Urrea was returned to Mexico. "General Bravo" is furthermore mentioned as being part of a flotilla including Fama and Vencedor del Alamo that arrived at Campeche in late August 1838 (Bonilla 1946:118).

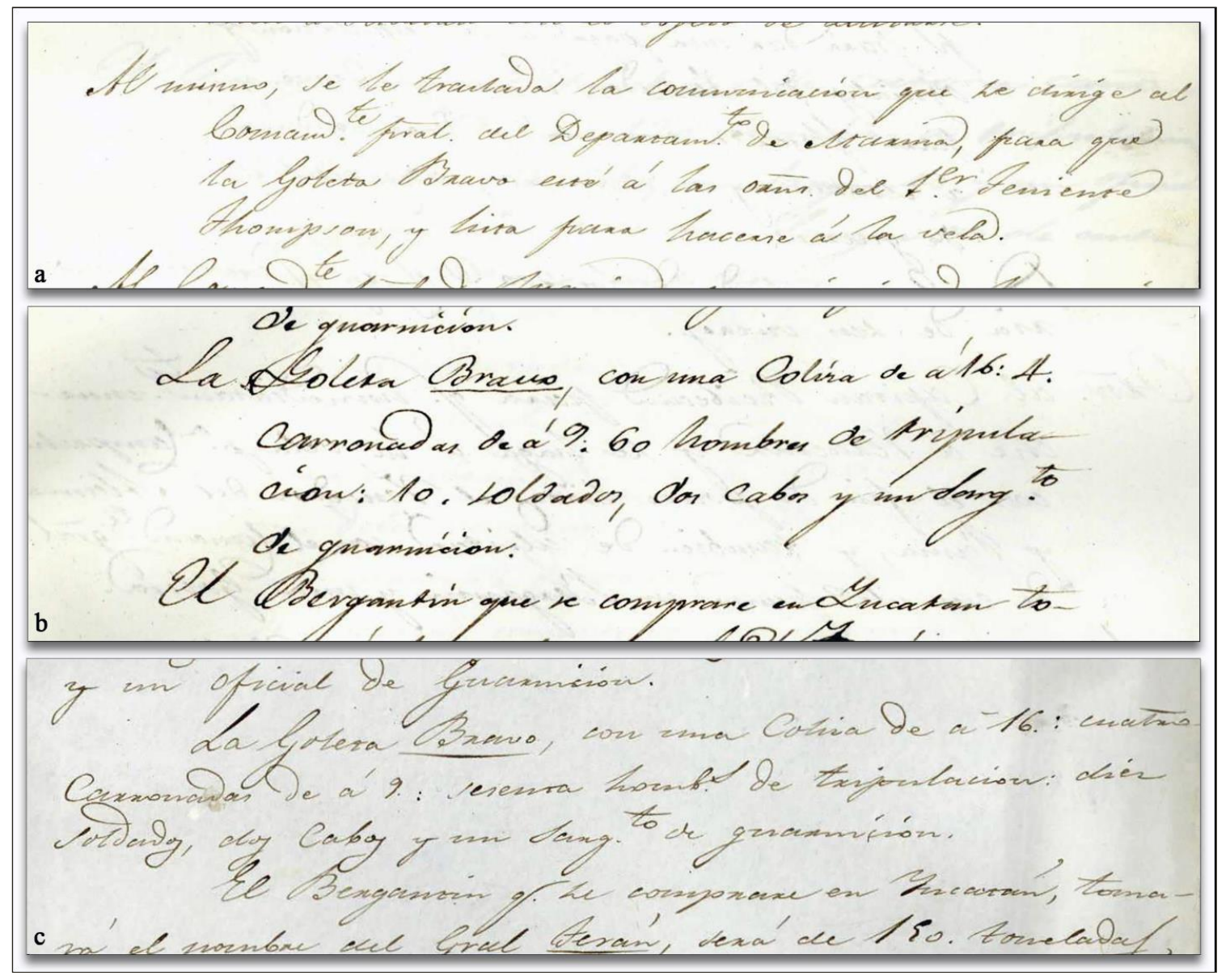

Figure 10. Mexican military documents referring to Bravo after its loss at Brazos Santiago in April 1836: (a) indicating Thompson as commander of Bravo and who is being asked to prepare Bravo to sail; (b) description of Bravo; and (c) copy of Bravo description. (Secretaria de Guerra y Marine 1836; Reibaud 1836). 
During the Pastry War between Mexico and France in 1838-1839, the French Navy captured the entire Atlantic fleet of the Mexican Navy at Veracruz on November 28, 1838, including the corvette Iguala; brigs Irtubide, Libertador, and Urrea; and schooners Terán and Bravo, before French forces returned to France in March of 1839 (Penot 1976:451; Meed 2001:109; Jordan 2006:116). It is believed all these vessels were fairly new acquisitions, built in Baltimore (Jordan 2006:116; Williams 2010) thought the original source of this information is not referenced.

Documentation suggests Iturbide, Libertador, Urrea, and Bravo were restored to Mexico in December 1838, though it appears Texas intended to acquire these captured prizes, evidenced by a new law to authorize such a purchase passed by the Texas Congress in 1838 (Wells 1988:4-5; Demerliac 2007:191). Additionally, the Memoria del secretario de estado y del despacho de la guerra of 1839 records that Iturbide had been sold by the French, Teran and Urrea had been disposed of, Iguala was still owned by France, and Bravo was at Tampico (von Mach, personal communication 2018). Some of these historic sources are not in agreement, so the fate of Bravo after the conclusion of the Pastry Wars is unclear.

\section{The Final Montezuma (1842-1843)}

Ultimately by 1842 , the various sailing vessels Moctezuma, Montezuma, Bravo, General Bravo, and Segundo Bravo appear to no longer be active. The Mexican Navy acquired a new state-of-theart warship, the 204-ft steamship Montezuma built by Greens and Wigrams in England and armed with one 68-pounder shell gun, two long 32 pounders, four 32-pounder carronades, and one small 9 pounder. It was outfitted with two 140 horsepower engines and had a displacement of 1111 tons (Hill 1987:172-173). It participated in the Battle of Campeche in 1843 but ultimately Mexico was unable to afford payment on the vessel and it was repossessed in 1846.

In summary, four armed vessels bearing the names Moctezuma, Montezuma, Bravo, General Bravo, and/or Segundo Bravo were in operation off the Texas and Mexican coasts between 1825 and 1846 - this quantity expands to five if it is believed the 1835 schooner Moctezuma legitimately sank at Bravos Santiago in April 1836. For simplicity they are listed in Table 3. 
Table 3. Armed Vessels Named Bravo, Moctezuma, or Montezuma in Operation in Mexico During the Early-to-Mid Nineteenth Century.

\begin{tabular}{|l|l|l|l|l|}
\hline No. & Name(s) & Vessel Type & Use Period & Armament \\
\hline 1 & Aerial/Bravo & Brig & $1825-$ ca. 1835 & $\begin{array}{l}\text { 14 24-pdr. Carronades; 18 } \\
\text { guns; or 20 carronades. }\end{array}$ \\
\hline 2 & Montezuma* $^{*}$ & Schooner & $?-1832$ & $\begin{array}{l}\text { A pivot cannon and two } \\
\text { other guns }\end{array}$ \\
\hline 3 & $\begin{array}{l}\text { Moctezuma, Montezuma, Bravo, } \\
\text { General Bravo, (Segundo Bravo?) }\end{array}$ & Schooner & $1834-1836 ?$ & 1 pivot cannon and 4 guns \\
\hline 4 & $\begin{array}{l}\text { Bravo, (Segundo Bravo?) } \\
\text { ** }\end{array}$ & Schooner & $1836 ?-1838$ & $\begin{array}{l}\text { 16-pdr. pivot cannon and } \\
\text { four 9-pdr. Carronades }\end{array}$ \\
\hline 5 & Steamship & $1842-1846$ & $\begin{array}{l}\text { 68-pdr. Shell gun, two long } \\
\text { 32 pdrs., four 32-pdr. } \\
\text { carronades, one small 9- } \\
\text { pdr. }\end{array}$ \\
\hline
\end{tabular}

${ }^{*}$ not part of the official Mexican Navy but used during a governmental coup.

**only a separate vessel if record no. 3 above truly sank in April 1836.

\section{OTHER LOWER RIO GRANDE VALLEY SHIPWRECKS}

Considerable time has been spent in an attempt to unravel the mystery behind Bravo and its loss as a means to investigate its promise as a wreck candidate for 41CF184. Other vessels sank in the general vicinity of the archeological site and these shipwrecks may be the key to realizing Boca Chica No. 2's role in Texas' history. Not much is known about most of these reported shipwrecks so the following discussion serves merely as an introduction to this still tantalizing puzzle-if not Bravo what could this shipwreck be?

As of January 2017 there are 297 historic shipwrecks in the THC's shipwreck database that have been reported in Cameron County: 49 are listed as being lost in or near the mouth of the Rio Grande River, approximately 120 wrecks are lost in Brazos Santiago harbor/pass, and nearly a dozen are reported near shore between the river mouth and the pass. In considering potential alternative candidates for 41CF184, all vessels near the mouth of the Rio Grande River were initially selected as well as those in the area of south Boca Chica Beach $(n=49)$. Nine of the vessels in this area were steamers and one was a barge -6 are unknown and the remaining 34 were sailing vessels that included 11 sloops, 2 barks, and lighters. Of the 21 verified two-masted sailing vessels from this group (Table 4), all were schooners. The THC database only has dimensions for two of these schooners, Lodi (wrecked 1832) and Liberty (wrecked 1892). 
Table 4. Two-Masted Vessel Losses near the Mouth of the Rio Grande River

\begin{tabular}{|c|c|c|c|c|c|c|c|c|}
\hline Vessel Name & $\begin{array}{l}\text { Year } \\
\text { Built }\end{array}$ & $\begin{array}{l}\text { Year } \\
\text { Lost }\end{array}$ & $\begin{array}{l}\text { Vessel } \\
\text { Type }\end{array}$ & Length & Breadth & $\begin{array}{l}\text { Depth } \\
\text { of Hold }\end{array}$ & $\begin{array}{l}\text { Cause } \\
\text { of } \\
\text { Loss } \\
\end{array}$ & Database Nos. ${ }^{*}$ \\
\hline Alice And Mary & - & 1863 & schooner & - & - & - & - & THC 671 \\
\hline Bonita & 1831 & 1837 & schooner & 60 & 19.3 & 5.9 & storm & THC 680, GOM 120 \\
\hline Caroline & - & & schooner & - & - & - & - & $\begin{array}{l}\text { THC } 687 \\
\text { THC 697, GOM }\end{array}$ \\
\hline Coffin & - & 1847 & schooner & - & - & - & storm & 1552 \\
\hline Emma & - & 1878 & schooner & - & - & - & - & THC 712 \\
\hline Farmer's Return & 1837 & 1842 & schooner & 60.6 & 19.6 & 5.6 & - & THC 719, GOM 411 \\
\hline $\begin{array}{l}\text { Florence Bernice } \\
\text { General C. C. }\end{array}$ & - & $1800 \mathrm{~s}$ & schooner & - & - & - & fire & THC 721 \\
\hline Pinckney & - & 1863 & schooner & - & - & - & - & THC 724 \\
\hline Halcyon & 1829 & 1836 & schooner & 72.5 & 22 & 8 & - & $\begin{array}{l}\text { THC 731, GOM } 513 \\
\text { THC 733, GOM }\end{array}$ \\
\hline Hunter & - & 1847 & schooner & - & - & - & & 1571 \\
\hline Ike Davis & - & 1864 & schooner & - & - & - & - & THC 736 \\
\hline James Duckett & - & 1865 & schooner & - & - & - & - & THC 739 \\
\hline Liberty & 1866 & 1892 & schooner & 66 & 21 & 4 & - & THC 756 \\
\hline Lodi & 1835 & 1836 & schooner & 71 & 21 & 6 & - & THC760, GOM 691 \\
\hline Louisiana & - & 1837 & schooner & - & - & - & - & $\begin{array}{l}\text { THC 761, GOM } 70 \\
\text { THC 765, GOM }\end{array}$ \\
\hline Mary Emma & - & 1847 & schooner & $\begin{array}{l}- \\
-\end{array}$ & - & - & - & $\begin{array}{l}1579 \\
\text { THC 766, GOM } \\
1578\end{array}$ \\
\hline Phoenix & - & 1834 & schooner & - & - & - & - & $\begin{array}{l}\text { THC 790, GOM } 913 \\
\text { THC 813, GOM }\end{array}$ \\
\hline Spartacus & 1834 & 1835 & schooner & 71.2 & 18.6 & 7.9 & - & $\begin{array}{l}1084 \\
\text { THC 828, GOM }\end{array}$ \\
\hline Virginia & - & 1847 & schooner & - & - & - & & $\begin{array}{l}1597 \\
\text { THC 832, GOM }\end{array}$ \\
\hline W. C. Preston & - & 1848 & schooner & - & - & - & - & 1595 \\
\hline
\end{tabular}

Cross-referencing the remaining 19 vessels against the author's personal database on early nineteenth-century regional watercraft only produced additional dimensions for Farmer's Return, Halcyon, Spartacus, and Bonita, though it is difficult to confirm if these are in fact the same vessels listed in the THC database. Without information such as the size, captain, city of build, or origin it can be hard to link vessels to register and enrollment data (Survey of the Federal Archives 1942) as many vessels shared the same names. The dimensions for the remaining 15 vessels in Table 4 
are still unknown. There are likely other shipwrecks that are unknown to the THC and not documented in the agency's database.

Bonita, Farmer's Return, and Liberty are smaller than 41CF184, though Lodi, Halcyon, and Spartacus are close in size. With a beam of $5.5 \mathrm{~m}$ (18 ft), Spartacus is too narrow for serious consideration as a candidate and Lodi is more than a foot shorter, though this may be nominal due to the inexactness in considering the true registration dimensions of 41CF184. The schooner Halcyon is the most similar in size to 41CF184, with registration dimensions of 22.1 (length) x 6.7 (breadth) $\times 2.4 \mathrm{~m}$ (depth) $(72.5 \times 22 \times 8 \mathrm{ft})$. It had a displacement of $11022 / 95$ tons. It was built is Sussex County, Delaware in 1829 and was first registered at Baltimore in 1831 (Survey of Federal Archives 1942:92). The first advertisement in the New Orleans Bee (1836b:2), discovered by the author, that lists it availability for Matamoras suggests it was not coppered as this was not described, which is typically the fashion for charter vessels at this time.

Halcyon was a well-known New Orleans schooner that cruised frequently between New Orleans and Matamoros. It was regularly advertised for Matamoros in the New Orleans Bee between May 7 and November 4, 1836 at which time it was under new ownership to Thomas Cucullu, Manuel Simon Cucullu, and Jean Martial Lapreyre (NOB 1836b:2, 1836c:1; Survey of Federal Archives 1942:92). They operated this vessel on behalf of M.S. Cucullu Lepeyre \& Co. and also acted as agents in the slave trade emanating from Havana. Halcyon was registered to this company on May 12 (NOB 1836d:1; Macauley and Lewis 1839; Survey of the Federal Archives 1942:92). Not only did it carry freight and passengers but was also used to convey dispatches and relay news of occurrences in Mexico to the newspapers (BMP 1835:2; NOB 1836e:1, 1836f:2; Huron Reflector 1836:2; The Morning Chronicle 1836b:1). In June and August 1836, it transported almost $\$ 200,000$ in specie from Matamoras to New Orleans (NOB 1836g:2;1836h:2; Huron Reflector 1836).

During one of its trips in the Gulf, Halcyon's crew became inadvertently involved in an international incident at Tampico, Mexico. General José Antonio Mexia conspired with supporters in New Orleans and Texas to plan and supply an expedition to attack Tampico, Mexico. After arriving off Tampico on November 14, 1835, Mexia's vessel grounded while trying to approach the city under the cover of night, his troops having to wade ashore during the early hours on November 13. The delay in landing allowed Mexican troops to prepare a response and Mexia and his troops were unsuccessful in their attempt to attack the town. His soldiers retreated and dispersed with many being taken prisoner. For an additional 10 days Mexia remained at the fort, but in the absence of expected reinforcements he chartered the schooner Halcyon for \$2000 to affect his return to New Orleans. He abandoned some of his troops, many of whom later claimed to not 
be aware of the true nature of the enterprise. They were tried and executed on December 14 (Gomez 1835; Barker 1903:171-177).

According to a list of shipwrecks compiled by historian by Albert Alfonso Champion and sent to the THC (Champion 1974), Halcyon sank at the mouth of the Rio Grande River in 1836. The THC has not been able to independently verify this wrecking event, though charter listings for Halcyon in the New Orleans Bee were not discovered after early November 1836, perhaps suggesting it sank towards the end of the year. An altogether different vessel, the copper-fastened and coppersheathed Mexicana, formerly advertised for general charter to Mexico, was specifically listed for Matamoros (as had been Halcyon) by November 22 (NOB 1836i:1, 1836j:2). Halcyon is not registered at New Orleans after May 12, 1836 (Survey of Federal Register 1942:92).

In general, 41CF184 is consistent with the size and wreck location of Halcyon and is only slightly larger than Spartacus - close enough to perhaps also maintain this latter schooner as a candidate. Halcyon was built in Sussex County, Delaware which is a regional source of baldcyprus and the northernmost occurrence of this species in the United States. Despite this circumstantial information, the dimensions of 41CF184 are fairly common for merchant vessels being used in the Gulf and the current analysis could easily be overlooking other potential historical candidates for which the hull dimensions are not known. Without more complete historical information regarding the known, and as yet undocumented historic wrecks in this region and in the absence of historic artifacts at $41 \mathrm{CF} 184$, it may not be possible to ever conclusively identify this significant State Antiquities Landmark.

\section{CONCLUSION}

As 41CF184 does not appear to contain any of its cultural material, likely salvaged at the time of its loss and in the years since, only its hull dimensions and characteristics may truly advance or eliminate historic vessels as candidates. Regardless of the complexity of the varying histories of Moctezuma, Montezuma, Bravo, General Bravo and whether or not one ultimately wrecked at Brazos Santiago or at the mouth of Rio Grande River, none of the available published studies on the Mexican and Texas Navies, associated archival documents, or regional histories perused by the author have included dimensions for these Mexican navy sailing vessels.

Historic evidence indicates the candidate Moctezuma, if it was successfully sunk by Invincible, went aground on the north side of the bar at Brazos Santiago Pass and not near the mouth of the Rio Grande River - the latter of which is the location of 41CF184. The reliability of these historic 
accounts and the strong possibility that Bravo did not sink, offer enough doubt to remove Bravo from consideration as a wreck candidate.

In addition, 41CF184 does not have any of the attributes that would typically identify this as a naval vessel of the period, especially one described as a clipper schooner. The hull dimensions, length-to-beam ratio, and absence of copper sheathing are more consistent with merchantman and in particularly a specific example (Halcyon) that frequented the area between 1835 and 1836. Other unknown or lesser documented vessels may equally qualify.

So the story of Moctezuma doesn't quite conclude, but merely teases a larger more complex narrative that also highlights the fallibility of historic and eyewitness accounts. The phantom ship is still elusive, not perhaps to its original pursuers in 1835 and 1836, but to those archeological investigators seeking that evidence of our history.

\section{ACKNOWLEDGEMENTS}

This article would not have been possible without the generosity and hard work of former State Marine Archeologist Steve Hoyt and the THC's Marine Stewards. The vigilant monitoring of the shipwreck since 1999 made this summary possible. A special thanks is extended to colleague, author, and historian Gregg Dimmick who has shared archival documents over the years, especially his more recent research that included papers on the Mexican Navy. Similarly, Andreas von Mach provided invaluable data on some of these historical vessels taken from his personal research. The THC extends its gratitude and thanks to Keith Reynolds for rescuing the foremast from 41CF184, an important and informative artifact, and to Bill Turner for coordinating its return to the THC. Additional thanks to David Camarena and Gregg Dimmick for assistance in translating aspects of the Mexican archival documents. Peter Rindlisbacher generously created the image of the battle between Invincible and Bravo expressly for this article.

My deepest gratitude is also extended to Boca Chica No. 2 investigators Steve Hoyt, Andy Hall, and Tom Oertling for their review of this article and editorial comments. These archeologists conducted the principle work on the shipwreck, which I myself (unfortunately) have never visited.

Publisher's Note: the author has prepared additional documentation on her topic that appears in a separate linked folder. The appendix will feature a sample of the photographs of Boca Chica No. 2 from the Texas Historical Commission's (THC) photography collection. There are currently more than 700 images for this shipwreck in the form of color slides, $35 \mathrm{~mm}$ print film, and digital photography. The images in the appendix are provided for research use only and are 
Copyrighted intellectual property of the Texas Historical Commission, Austin, Texas. They may NOT to be used in any publication format without express written permission of the Agency. If there is an interest in using these photographs for publication, marketing, or any commercial use, please contact the THC regarding the agency's image use policy. Please allow for a lengthy download time due to file size. Click here for the Appendix. 


\section{REFERENCES}

Añorga, Juan

1835 Mexican Schooner Bravo Ship's Log. Dolph Briscoe Center for American History, The University of Texas at Austin.

Arnold, J Barto and Robert Weddle,

1978 The Nautical Archeology of Padre Island. Academia Press, New York, New York.

Bancroft, Hubert Howe

1889 The Works of Hubert Howe Bancroft, Vol. XVI, History of the Mexican States and Texas. The History Company Publisher, San Francisco, California.

Barker, Eugene C.

1903 The Tampico Expedition. The Quarterly of the Texas State Historical Association 6(3):169-186.

Barrett, Don Carlos

1836 Resolution presented to the General Council, Council Hall, San Felipe de Austin 8 January. In Journal of the Proceedings of the General Council of the Republic of Texas Nov 14th 1835, pp. 283-284. National Intelligencer, Houston, Texas, 1839.

Bidwell, Robert L.

1960 The First Mexican Navy 1821-1830. Ph.D. dissertation, Corcoran Department of History, University of Virginia, Charlottesville, Virginia.

Bonilla, Juan de Dios

1946 Apuntes para la Historia de la Marina Nacional. Mexico.

Borgens, Amy and Amber Cabading

2016 Foremast Documentation, 41CF184. Manuscript on file, Marine Archeology Program, Texas Historical Commission, Austin, Texas.

Borgens, Amy

2008 Historic Context in Ben Ford, Amy Borgens, William Bryant Dawn Marshall, Peter Hitchcock, Cesar Arias, and Donny Hamilton, Archeological Excavation of the Mardi Gras Shipwreck (16GOM01), Gulf of Mexico Continental Slope, pp. 39-74, U.S. Department of Interior, Minerals Management Service, Gulf of Mexico OCS Region, OCS Report MMS 2009-037, New Orleans, Louisiana.

2010 Field Investigation of Unknown Beach Site, North Padre Island, Willacy County. In Texas Historical Commission Annual Report for Permit No. 2035, September 2009-August

2016a Recovery of the Foremast from State Antiquities Landmark 41CF184. In Texas Historical Commission Annual Report for Permit No. 2035, September 2015-August 2016. pp. 2-4. Manuscript on file, Marine Archeology Program, Texas Historical Commission, Austin, Texas. 
2016b Preliminary Observations on the Recent Beached Shipwreck at Boca Chica in Texas Historical Commission Annual Report for Permit No. 2035, September 2015-August 2016. pp. 16-21. Manuscript on file, Marine Archeology Program, Texas Historical Commission, Austin, Texas.

Boston Morning Post (BMP) [Boston, Massachusetts]

1835 The New Orleans American of the 4th instant says-. 27 November:2. Boston, Massachusetts.

1836 Very Important from Mexico. 6 September:1. Boston, Massachusetts.

1837a From Mexico. 6 March:2. Boston, Massachusetts (Toro on board)

1837b From Mexico 24 July:2. Boston, Massachusetts (Thompson desertion)

Boudriot, Jean

1986 The Seventy-Four Gun Ship: A Practical Treatise on the Art of Naval Architecture. Vol. 2, Fitting Out the Hull. Translated by David H. Roberts. Naval Institute Press, Paris.

British Traveler and Commercial and Law Gazette [London, Middlesex],

1832 Foreign Intelligence. 17 October 17:2. London, Middlesex.

Brown, Jeremiah

1836 Letter to James Morgan. Galveston Harbor, 7 April. In Official Correspondences of the Texas Revolution 1835-1836, Vol. II, edited by William C. Brinkley, p. 605. 1936 Appleton-Century Company, Inc., New York, New York.

Bryan, M. A.

1835 Letter to James F. Perry, 2 miles from Bexar. In The Austin Papers October 1834-January 1837, edited by Eugene C. Barker, p 217. 1927 University of Texas Press, Austin, Texas, 1927.

Bush, Leslie L.

2016 Wood from Five Shipwrecks in the Gulf of Mexico. Manuscript on file, Marine Archeology Program, Texas Historical Commission, Austin, Texas.

Champion, Albert A.

1974 Letter to J. Barto Arnold of the Texas Antiquities Committee, 26 April. Manuscript on file, Marine Archeology Program, Texas Historical Commission, Austin, Texas.

Covington Western Constellation [Covington, Indiana]

1836 Naval Engagement. May 20:2. Covington, Indiana.

Dawson, Frederick and Samuel M. Williams

1839 Document A. Contract for one Ship, two Brigs, and three Schooners, pp 13-22. In Annual Report of the Secretary of the Navy, November 1839. Whitings Print.

Demerliac, Alain

2007 La Marine de la Restauration et de Louis-Philippe 1er: Nomenclature des navires Français de 1815 á 1848. A.N.C.R.E. Nice, France. 
Dienst, Alexander

1909a The Navy of the Republic of Texas, I, The First Navy of Texas. The Quarterly of the Texas State Historical Association 2(3):165-203.

1909b The Navy of the Republic of Texas, II, The First Navy of Texas. The Quarterly of the Texas State Historical Association 12(4):249-275.

Drake, Jerry

2005 The Search for Two Ancient Adversaries. Texas Navy Association. Electronic document, http://www.texasnavy.com/resources/Documents/Historical/Ships/Discovery of what_is_possibly the Montezuma.pdf, accessed on February 18, 2015.

Escamilla, Juan Ortiz

2008 El teatro de la guerra: Veracruz 1750-1825 Publicaciones de la Universidad Jaume, Castelló de la Plana, Spain.

Espino, Jose Maria

1836 Letter to Fernando Fernandez, DATE. In Partes de Las 223. Comandancias Generales de Matamoros, Tamps., Veracruz Y Yucatan, Dando Cuenta del Movimiento Dd Barcos con Motivo de la Campana de Texas. Ano de 1836, pp. 67-70. Archivo Expediente Histórico Militar XI/481.3/1656. Electronic document, http://www.archivohistorico2010.sedena.gob.mx/busqueda/MostrarImg.php; (now http://www.archivohistorico2010.sedena.gob.mx/mostrarimagen?expid=20589\&expno=1656), accessed by Gregg Dimmick October 2013.

Fannin, James W.

1835 Letter to Daniel W. Smith, 11 December. In The Papers of the Texas Revolution, 1835-1836, Vol. 3, edited by John H. Jenkins, pp. 158-160. 1973 Presidial Press, Austin, Texas.

Filosola, D. Vincent

1849 Memorias para la historia de la guerra de Tejas, Volume 1. Imprente de Ignacio Cumplido, Mexico.

Fischer, Ernest G.

1976 Robert Potter: Founder of the Texas Navy. Pelican Publishing Company. Gretna, Louisiana.

Fisher, Samuel Rhodes

1835 Letter to Public, 11 Jan. In The Papers of the Texas Revolution, 1835-1836, Vol. 4, edited by John H. Jenkins, pp. 211-219. 1973 Presidial Press, Austin, Texas.

1836 Audited Claim. Republic Claims, Texas Comptroller's Office. Archives and Information Services Division, Texas State Library and Archives Commission. 
Fleury, Anthony B.

ca. 1874Pension Claim. Republic Claims, Texas Comptroller's Office. Archives and Information Services Division, Texas State Library and Archives Commission.

Ford, Ben, Amy Borgens, William Bryant, Dawn Marshall, Peter Hitchcock, Cesar Arias, and Donny Hamilton

2008 Archaeological Excavation of the Mardi Gras Shipwreck (16GM01), Gulf of Mexico Continental Slope. U.S. Department of Interior, Minerals Management Service, Gulf of Mexico OCS Region, OCS Report MMS 2009-037, New Orleans, Louisiana.

Ford, Ben, Amy Borgens, and Peter Hitchcock

2010 The Mardi Gras Shipwreck: Results of a Deep-Water Excavation, Gulf of Mexico, USA. The International Journal of Nautical Archaeology 39:76-98.

Forsyth, Mr.

1836 Letter to Mr. Ellis, Department of State, Washington, 20 July. Washington Globe 3

February:3. Washington DC.

General Council (Texas)

1835 Journal of the Proceedings of the General Council of the Republic of Texas Nov 14th 1835. 1839 National Intelligencer, Houston, Texas.

Gomez Palomino, Gregorio

1835 Letter and Report to Santa Anna, Matamoros 30. Broadside dated November 26, 1835. Reel: 14 Texas as a Province and Republic 1795-1845. Reel: 14 Texas as a Province and Republic 1795-1845. Electronic document, http://www.essaydocs.org/texas-as-a-province-and-republic1795-1845-author-index.html?page=81, assessed August 5, 2015.

Grajales, Gloria

1969 Guia de documentos para la historia de Mexico en archivos ingleses Siglo 29. Universidad Nacional Autonoma de Mexico, Mexico.

Gray, William Fairfax

1909 From Virginia to Texas, 1835: Diary of Col. Wm. F. Gray. Gray, Dillate \& Co., Printers, Houston, Texas.

Gritton, Eduardo

1835 Letter to Domingo de Ugartechea, Gonzales, 5 July. In The Papers of the Texas Revolution, 1835-1836, Vol 1, edited by John H. Jenkins, pp. 203-205. 1973 Presidial Press, Austin, Texas.

Guerra, J.M.

1835 Letter to Daniel W. Smith, 14 December. In The Papers of the Texas Revolution, 1835-1836, Vol. 3, edited by John H. Jenkins, p. 188. 1973 Presidial Press, Austin, Texas. 
Hall, Andrew, John Luce, and Doug Nowell

2002 Field Report: Boca Chica Wreck. Manuscript on file, Marine Archeology Program,Texas Historical Commission, Austin, Texas

Hall, William

1835 Letter to Stephen F. Austin. In The Austin Papers October 1834-January 1837, edited by Eugene C. Barker, pp. 264-265. 1927 University of Texas Press, Austin, Texas.

Hayes, Charles W.

1974 [1879] History of the Island and the City of Galveston. Cincinnati, Ohio. 1974 fascmile ed. Jenkins Garrett Press, Austin, Texas.

Hill, Dan

1987 The Texas Navy: in Forgotten Battles and Shirtsleeve Diplomacy. Reprinted. State House Press, Austin, Texas. Originally published 1937, University of Chicago Press, Chicago, Illinois.

Horrell Chris and Amy A. Borgens

2017 The Mardi Gras Shipwreck Project: A Final Overview with New Perspective. Historical Archaeology 51(3):433-450.

Hoyt, Steven D.

1999a Boca Chica Emergency Shipwreck Investigation. In Texas historical Commission Annual report for Antiquities Permit No. 2035. Manuscript on file, Marine Archeology Program, Texas Historical Commission, Austin, Texas.

1999b Boca Chica \#2 Field Investigations. 5 May. Manuscript on file, Marine Archeology Program, Texas Historical Commission, Austin, Texas.

2002a Boca Chica No. 2-41CF184. In Texas historical Commission Annual Report for Antiquities Permit No. 2035, pp. 3-4. Manuscript on file, Marine Archeology Program, Texas Historical Commission, Austin, Texas.

2002b Boca Chica \#2 Revisited, 9 May. Manuscript on file, Marine Archeology Program, Texas Historical Commission, Austin, Texas.

Hunt, Richard S and Jesse E. Randel

1841 Karte von Texas entworfen nach den Vermessungen, welche in den Acten der General-LandOffice der Republic liegen bis zum Jahr 1839 von Richard S. Hunt \& Jesse F. Randel. In George A. Scherpf, Entstehungsgeschichte und gegenwärtiger Zustand des neuen, unabhängigen, amerikanischen Staates Texas. Ein Beitrag zur Geschichte, Statistik und Geographie dieses Jahrhunderts, Im Lande selbst gesammelt von G. A. Scherpf. Mit zwei Karten, von Texas, Rio Grande und dem West-Land am Stillen Ocean Augsburg. Verlag der Matth. Rieger'schen Buchhandlung, 1841. Perry-Castañeda Library Historical Maps of Texas, Republic of Texas 1836-1845. Map Collection. Electronic document, http://www.lib.utexas.edu/maps/historical/scherpf-texas-1841.jpg, accessed Oct 2, 2016. 


\author{
Huron Reflector [Norwalk, Ohio] \\ 1836 From Matamoras (Reprinted from the New Orleans Commercial Bulletin) 10 August:2. \\ Norwalk. \\ Jones, Charles C. \\ 1878 The Life and Services of Commodore Josiah Tattnall. Morning. News Steam Printing House, \\ Savannah, Georgia. \\ Jordan, Jonathon W. \\ 2006 Lone Star Navy: Texas, the Fight for the Gulf of Mexico, and the Shaping of the American West. \\ Potomac Books, Inc., Washington D.C. \\ Kent and Essex Mercury [London, Middlesex] (UK) \\ 1824 Kent. 17 May:4. London, Middlesex. \\ Kauffman, Henry J. \\ 1968 American Copper and Brass. Thomas Nelson \& Sons, Camden, New Jersey. \\ Lerdo de Tejada, Miguel M. \\ 1857 Apuntes Historicos de la Herioica Cuidad de Vera-Cruz. Imprente de Vincent Garcia Garcia \\ Torres, Mexico. \\ Livingston, Edward \\ 1832 Letter to Jose Montoya. October 26. 678-679. In Executive Documents: 13th Congress, $2 \mathrm{~d}$ \\ Session-49th Congress, 1st Session, Volume 12, pp. 676-677. Government Printing Office, \\ Washington D.C. \\ London Lloyd's List (LLL) [London, Middlesex] (UK) \\ 1825a Gravesend. 12 July:1. London, Middlesex. \\ 1825b Deal. 15 July:1. London, Middlesex. \\ 1825c Falmouth. 2 August:2 London, Middlesex. \\ 182729 May:1. London, Middlesex. \\ London Morning Post (LMP) [London, Middlesex] (UK) \\ 182829 September:3. London, Middlesex. \\ 183610 June:5. London, Middlesex. \\ London Public Ledger [London, Middlesex] (UK) \\ 183516 December:3. London, Middlesex. \\ London Shipping Gazette [London, Middlesex] (UK) \\ 1836 American Papers. 12 September:1. London, Middlesex. \\ London St. James Chronicle and General Evening Post [London, Middlesex] \\ 183524 November:4. London, Middlesex.
}


Long, David F.

2014 Nothing to Daring: A Biography of Commodore David Porter 1780-1843. Naval Institute Press, Annapolis Maryland.

Lyman, John

1945 Register Tonnage and Its Measurement. The American Neptune 5(3):223-234.

Macauley H.W and W.W. Lewis

1839 Letter to Viscount Palmerston. In Class A, Correspondence with the British Commissioners at Sierra Leone, The Havana, Rio de Janiero, and Surinam Relating to the Slave Trade, p. 62. 1841. W. Cloves and Sons, London.

McKinney, Thomas F.

1835a Letter to President of the Council, Quintana, 11 Nov. In Official Correspondences of the Texas Revolution 1835-1836, Vol. II, edited by William C. Brinkley, pp. 65-66. Appleton-Century Company, Inc., New York New York.

1835b Letter read to the General Council. San Felipe de Austin, 11 October. In. Journal of the Proceedings of the General Council of the Republic of Texas, p. 10. National Intelligencer, Houston, Texas, 1839.

McKinney, Thomas F. and Samuel M. Williams

1835a Letter to R.R. Royal, Quintana, 29 Oct. In Official Correspondences of the Texas Revolution 18351836, Vol. II, edited by William C. Brinkley, pp. 26-27. Appleton-Century Company, Inc., New York New York.

1835b Letter to R.R. Royal, Quintana, 9 Nov. In Official Correspondences of the Texas Revolution 18351836, Vol. II, edited by William C. Brinkley, pp. 63-64. Appleton-Century Company, Inc., New York New York.

McMullen, John

1836 To the People of Texas. In Journal of the Proceedings of the General Council of the Republic of Texas, Held at San Felipe de Austin, November 14th 1835, pp. 297-302. National Intelligencer, Houston, Texas 1839.

Meed, Douglas V.

2001 The Fighting Texas Navy 1832-1843. Taylor Trade Publishing, Boulder. Colorado.

Mexico Ministerio de Hacienda

1837 Memoria de la Hacienda General de la Repúblic a Mexicana; presentadad á las Cámaras por el Ministro el Ramo en 29 de Julio de 1837. Imprenta del Águila, Mexico.

Michelena, José Mariano de

1825 Letter to Gómez Pedraza, October 30, 1825. Juan E. Hernández y Dávalos Manuscript Collection, Benson Latin American Collection, General Libraries, The University of Texas at Austin. 
Montoya, Jose M.

1832 Letter to Edward Livingston. October 11. In Executive Documents: 13th Congress, 2d Session-49th Congress, 1st Session, Volume 12:676-677. Government Printing Office, Washington D.C.

Morning Chronicle (MC) [London, Middlesex]

1836a America. 10 June:4 London, Middlesex.

1836b American Papers. 7 November:1. London, Middlesex.

New Albany Gazette [New Albany, Mississippi]

1836 From the Louisiana Advertiser, May 2. 20 May:2. New Albany, Mississippi.

New Orleans Bee (NOB) [New Orleans]

1836a Mexican Traders. For Matamoras. 29 November:1. New Orleans.

1836b Mexican Traders. For Matamoras. 7 May:2. New Orleans.

1836c Mexican Traders. For Matamoras. 4 November:1. New Orleans.

1836d Mexican Traders. For Matamoras. 9 May:1. New Orleans.

1836e Mexican Traders. For Matamoras. 1 November:1. New Orleans.

$1836 \mathrm{f}$ From Mexico. 10 August:2. New Orleans.

$1836 \mathrm{~g}$ Arrived. 20 June:2. New Orleans.

1836h Imports. 10 August:2. New Orleans.

1836i Mexican Traders. For Freight or Charter. 17 November:2. New Orleans.

1836j Mexican Traders. For Matamoras. 22 November:1. New Orleans.

New Times [London, Middlesex]

1827 Mexican and Spanish Squadrons. 26 April 1826:2 London

Niles Weekly Register [Baltimore, Maryland]

1832 Miscellaneous, 6 October:82-83. Baltimore, Maryland.Oertling, Thomas

Oertling, Thomas

2002 Personal report on the Boca Chica Wreck, Cameron County, Texas. Survey by the Marine Steward's Program, August 16-17 ${ }^{\text {th }}$ (Fri-Sat), 2002. Manuscript on file, Marine Archeology Program, Texas Historical Commission, Austin, Texas.

Penot, Jacques

1976 Les relations entre la France \& le Mexique de 1808 à 1840: un chapitre d'histoire écrit par les marins et diplomates français, Volume 1. Atelier Reproduction des thèses, Université Lille. Paris, France.

Pering, Richard

1812 Brief Enquiry into the Causes of Premature Decay in our Wooden Bulwarks with an Examination of the Means, Best Calculated to Prolong their Duration. L. Congdon, Plymouth-Dock (Devonport). 
Pierce, Frank

1917 A Brief History of the Lower Rio Grande Valley. George Banta Publishing Company, Menasha, Wisconsin.

Porter David, D.

1875 Memoir of Commodore David Porter of the United States Navy. J. Munsell Publisher, Albany, New York.

Procurador del Pueblo [Veracruz]

1834 Capitania del Puerto. 18 April. Veracruz

Powers, John

2006 The First Texas Navy. Woodmont Books. Austin, Texas.

Reibaud, D. Franciso

1836 Letter. July 20 pp 141-142. In Partes de Las 223. Comandancias Generales de Matamoros, Tamps., Veracruz Y Yucatan, Dando Cuenta del Movimiento Dd Barcos con Motivo de la Campana de Texas. Ano de 1836318 Fojas. Archivo Expediente Histórico Militar XI/481.3/1656. Electronic document, http://www.archivohistorico2010.sedena.gob.mx/busqueda/MostrarImg.php; (now http://www.archivohistorico2010.sedena.gob.mx/mostrarimagen?expid=20589\&expno=1656), accessed by Gregg Dimmick October 2013.

Ronnberg, Erik A. R.

1980 The Coppering of 19th Century American Merchant Sailing Ships. Nautical Research Journal, 26 (3):125-148.

Secretaria de Guerra y Marine

1836 Memorandum. In Partes de Las 223. Comandancias Generales de Matamoros, Tamps., Veracruz Y Yucatan, Dando Cuenta del Movimiento Dd Barcos con Motivo de la Campana de Texas, pp. 137-140. Ano de 1836318 Fojas. Archivo Expediente Histórico Militar $\mathrm{XI} / 481.3 / 1656$. Electronic document, http://www.archivohistorico2010.sedena.gob.mx/busqueda/MostrarImg.php; (now http://www.archivohistorico2010.sedena.gob.mx/mostrarimagen?expid=20589\&expno=1656), accessed by Gregg Dimmick October 2013.

Scheina, Robert L.

1969 Vessels of the Mexican Navy 1846-1848. In Surfboats and Horse Marines: U.S. Naval Operations in the Mexican War, by K. Jack Bauer. United States Naval Institute, Annapolis, Maryland.

1970 The Forgotten Fleet: The Mexican Navy on the Eve of War, 1845. American Neptune 30(1):46-55. 
Smith, D.C.

1835 Letter to Principal Commandant of the State of Tamaulipas, 12 December. In The Papers of the Texas Revolution, 1835-1836, Vol. 3, edited by John H. Jenkins, p. 173. Presidial Press, Austin, Texas, 1973.

Staniforth, Mark

1985 The Introduction and Use of Copper Sheathing-A History. Australian Institute of Maritime Archaeology, 9(1, 2):21-48.

Steffy, Richard

1994 Wood Ship Building and the Interpretation of Shipwrecks. Texas A\&M Press, College Station, Texas.

Survey of Federal Archives in Louisiana

1941 Ship Registers and Enrollments of New Orleans, Louisiana, Vol. 1, 1804-1820. Survey of Federal Archives in Louisiana, Service Division, Works Progress Administration, Hill Memorial Library, Louisiana State University, Baton Rouge.

1942 Ship Registers and Enrollments of New Orleans, Louisiana, Vol. 3, 1831-1840. Survey of Federal Archives in Louisiana, Service Division, Works Progress Administration, Hill Memorial Library, Louisiana State University, Baton Rouge.

Telegraph and Texas Register [San Felipe de Austin, Texas].

1836 San Felipe de Austin, 9 January:2. [San Felipe de Austin, Texas].

Tenori, Antonio

1835a Letter. Anahuac, 7 May. Microfilm, Roll 165, General Manuscript Series, 1717-1836, Béxar Archives, Briscoe Center for American History at the University of Texas at Austin, Austin.

1835b Letter to Domingo de Ugartechea, 18 May. Microfilm, Roll 165, General Manuscript Series, 1717-1836, Béxar Archives, Briscoe Center for American History at the University of Texas at Austin, Austin.

Tornel, Don Jose Maria

1836 Letter to Mr. Jose Maria Ortiz Monasterio, Mexico, 15 June. In Congressional Series of United States Public Documents, Volume II, p. 115. Gales and Seaton, Printers, Washington D.C. 1837.

Viele, John

1999 The Florida Keys, Vol. 2: True Stories of the Perilous Straights. Pineapple Press, Inc. Sarasota Florida.

Ward, Henry G.

1828 Mexico in 1827. Harry Colburn, London.

Washington Globe [Washington D.C.]

1835 From a New Orleans Paper. 24 June:2. Washington D.C. 
Washington National Intelligencer [Washington D.C.]

1832 New Orleans Aug. 30. 15 September:3. Washington D.C.

Wells, William R.

1998 "Every Protection that was Asked for..." The United States Revenue Cutter Ingham, Texas Independence, and New Orleans 1835. Journal of the Louisiana Historical Association 30 (4):457479.

Webster, Joseph Dana; Mullowny, T. E.; Schedler, J.

1847 Map of the Country Adjacent to the Left Bank of the Rio Grande below Matamoros. In en. Ex. Doc. 1 sess. 31st Congress, No. 65. Ackerman, New York, New York. Electronic document, http://library.uta.edu/usmexicowar/collections/image/usmw-500028.jpg, accessed March 16, 2017.

Williams, C. Herndon,

2010 Texas Gulf Coast Stories. Acadia Publishing.

Wilson, James T. D.

1874 Pension Claim. Republic Claims, Texas Comptroller's Office. Archives and Information Services Division, Texas State Library and Archives Commission.

York Herald and General Advertiser [York, North Yorkshire] (UK)

1825 Domestic. 15 October:2. York, North Yorkshire.

Zimmerman, Walter

1836 Letter to Eliza Zimmerman. Texas Navy Record Subject File, Vol. 1836-1860. Box 689 National Records and Archives Administration (NARA). 